\title{
Formation and Evolution of Secondary Particulate Matter During Heavy Haze Pollution Episodes in Northeast China in Winter
}

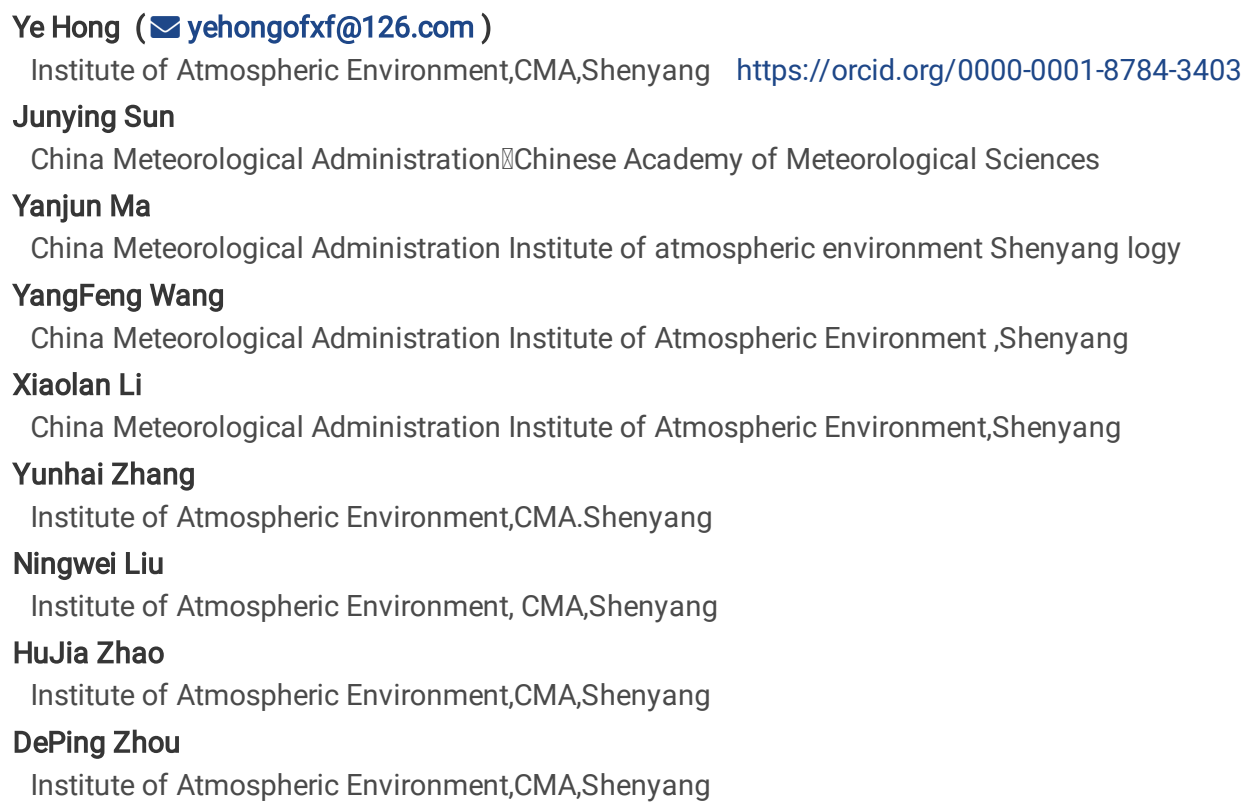

\section{Research Article}

Keywords: Haze, PM2.5, northeast China, chemical composition, meteorological factors

Posted Date: December 13th, 2021

DOI: https://doi.org/10.21203/rs.3.rs-987566/v1

License: @ (i) This work is licensed under a Creative Commons Attribution 4.0 International License. Read Full License 


\section{Abstract}

Based on the simultaneous observation of fine particulate matter $\left(\mathrm{PM}_{2.5}\right)$ and its chemical components in four heavy haze pollution episodes at 14 sampling sites in northeast China from 2017 to 2019, the formation and existence of sulfate $\left(\mathrm{SO}_{4}{ }^{2-}\right)$ and nitrate $\left(\mathrm{NO}_{3}{ }^{-}\right)$secondary contaminants under different stages of the pollution episodes, and different meteorological and emission conditions were compared. The results yielded three main findings. (1) Organic carbon (OC) was the most important component of $\mathrm{PM}_{2.5}$, followed by $\mathrm{NO}_{3}{ }^{-}, \mathrm{SO}_{4}{ }^{2-}$, and ammonium ( $\mathrm{NH}_{4}{ }^{+}$). $\mathrm{Nitrate}$ surpassed sulfate as the most important secondary inorganic component over the study period. (2) The significant increase in atmospheric $\mathrm{OC}, \mathrm{SO}_{4}{ }^{2-}$, and $\mathrm{NO}_{3}{ }^{-}$ concentrations was an important reason for haze formation. Meteorological factors such as wind direction, wind speed, temperature ( $\mathrm{T}$ ), relative humidity $(\mathrm{RH})$, and atmospheric oxidability played an important role in secondary pollutant formation. (3) There were two potential $\mathrm{SO}_{4}{ }^{2-}$ formation mechanisms. The first was the gas-phase reaction of the hydroxyl radical $(\mathrm{OH} \cdot)$ leading to the oxidation of nitrogen dioxide $\left(\mathrm{NO}_{2}\right)$ and sulfur dioxide

$\left(\mathrm{SO}_{2}\right)$, and high ozone $\left(\mathrm{O}_{3}\right)$ concentrations. A high atmospheric oxidability and high winter Ts were very important for $\mathrm{SO}_{4}{ }^{2-}$ formation. The second

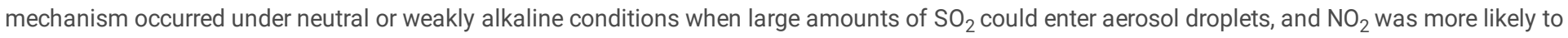
react in the aqueous phase with $\mathrm{SO}_{2}$ to increase the output of $\mathrm{SO}_{4}{ }^{2-}$. Nitrate formation was may be mainly due to the homogeneous gas-phase reaction of $\mathrm{OH}$. with $\mathrm{NO}_{2}, \mathrm{SO}_{2}$, and ammonia $\left(\mathrm{NH}_{3}\right)$. The highest $\mathrm{NO}_{3}$ concentration was observed under mild winter Ts, high $\mathrm{RH}$, high atmospheric oxidability $\left(\mathrm{O}_{3}\right.$ and nitrous acid ( $\left.\mathrm{HONO}\right)$ ), high $\mathrm{NH}_{3}$ concentrations, and suitable light conditions. The differences in $\mathrm{SO}_{4}{ }^{2-}$ formation between northeast China and other regions were mainly a result of the suppression of the aqueous reaction of $\mathrm{SO}_{4}{ }^{2-}$ due to the low $\mathrm{T}$ in winter and low-sulfur coal emissions, which resulted in the gas-phase oxidation process with the highest $\mathrm{SO}_{4}{ }^{2-}$ production capacity becoming an important process. However, the aqueous reaction process was the most common mechanism of $\mathrm{SO}_{4}{ }^{2-}$ production in northeast China.

\section{Introduction}

There has been an increase in haze pollution in northeast China in recent years. The causes of haze pollution and the formation of the major chemical pollutants are not well understood. Northeast China is located in the mid-high latitudes of the northern hemisphere and is an area with large anthropogenic emissions (van Donkelaar et al., 2016). It is also one of the regions of the world where the terrestrial climate is warming the most rapidly due to global climate change. The rate of increase in the winter surface temperature ( $T$ ) is significantly higher than the Chinese and global average(Zhao et al., 2007). This change will have an impact on the regional and global climate (Sobhaniet al., 2018). During heavy haze periods in northeast China, aerosols make the most significant contribution to organic carbon (OC) and secondary inorganic components (e.g., sulfate $\left(\mathrm{SO}_{4}{ }^{2-}\right)$ and nitrate $\left.\left(\mathrm{NO}_{3}{ }^{-}\right)\right)$in the atmosphere( $\mathrm{Li}$ et al.,2019). Both can account for more than $50 \%$ of fine particulate matter $\left(\mathrm{PM}_{2.5}\right)$ and play a pivotal role in haze formation (Zhang et al., 2020). Therefore, clarifying the causes of secondary aerosol formation is the key to understanding the causes of the persistent heavy haze in this region.

The occurrence of haze pollution is closely related to the chemical reactions between polluted particles in the air. Various physical processes and chemical reactions occur between different ions under different meteorological conditions, which strengthens the photochemical effect of haze particles and is the internal promoting factor of the "explosive" nature and "sustainability" of strong haze pollution (Wang et al.,2014). Sulfate in the atmosphere is mainly formed by the photochemical oxidation of sulfur dioxide $\left(\mathrm{SO}_{2}\right)$, which can be formed either by gas-phase homogeneous reactions or aqueous heterogeneous oxidation reactions. Studies have shown that the gas-phase oxidation is mainly the gas-phase oxidation of $\mathrm{SO}_{2}$ by the hydroxyl radical $(\mathrm{OH} \cdot)$, and aqueous oxidation occurs mainly in cloud/fog water droplets or aerosols, under the catalysis of transition metal ions (TMIs), e.g., $\mathrm{Fe}(\mathrm{III})$ and $\mathrm{Mn}(\mathrm{II})$, the oxidation of $\mathrm{S}(\mathrm{IV})$ by hydrogen peroxide $\left(\mathrm{H}_{2} \mathrm{O}_{2}\right)$, ozone $\left(\mathrm{O}_{3}\right)$, organic peroxides and oxygen $\left(\mathrm{O}_{2}\right)$, of which aqueous oxidation is the main $\mathrm{SO}_{4}{ }^{2-}$ formation pathway worldwide (Wang et al., 2021). Its generation rate is closely related to the $\mathrm{pH}$ of the particulate matter. Under acidic conditions, the catalytic oxidation of transition metals accounts for more than $90 \%$ of the generation, while under near-neutral conditions, the oxidation of $\mathrm{H}_{2} \mathrm{O}_{2}$ and nitrogen dioxide $\left(\mathrm{NO}_{2}\right)$ each account for $50 \%$ (Wang, 2021a). A typical feature of the heavy pollution in northern China in winter is a rapid increase in the $\mathrm{SO}_{4}{ }^{2-}$ concentration, and the sulfur oxidation rate increases exponentially with an increase in the relative humidity ( $\mathrm{RH}$ ) (Elser et al., 2016). This indicates that the heterogeneous chemical reaction under a high $\mathrm{RH}$ is an important pathway for $\mathrm{SO}_{4}{ }^{2-}$ formation during heavy haze pollution episodes (Zheng et al., 2015). Through a smoke box simulation study, Wang (2016a) found that the liquid(aqueous) phase oxidation of $\mathrm{SO}_{2}$ by $\mathrm{NO}_{2}$ on $\mathrm{PM}_{2.5}$ in China's atmosphere is an important $\mathrm{SO}_{4}{ }^{2-}$ formation mechanism during haze periods in China. The Ge research group has reported (Wang et al., 2021b) that the $\mathrm{SO}_{4}{ }^{2-}$ formation mechanism in eastern China in winter is mainly due to the rapid catalytic oxidation of $\mathrm{SO}_{2}$ by manganese $(\mathrm{Mn})$ ions on the surface of aerosols under low T and high RH conditions. The high ionic strength of the aerosol greatly enhances this reaction. The reaction rate is two to three orders of magnitude higher than that of the traditional aqueous reaction, which can explain $92.5 \%$ of the $\mathrm{SO}_{4}{ }^{2-}$ formation. Meteorological factors are very important for haze formation. Sun et al. (2016) used aerosol mass spectrometry to study the generation and elimination mechanisms of typical heavy haze pollution. It is believed that the synergistic influence of meteorology and chemistry is the key to the generation and elimination of haze. Static and stable meteorological conditions, high pollution emissions and rapid secondary aerosol formation are important factors in haze formation, especially the proportion of secondary particles during periods of heavy pollution, which can account for as much $70 \%$ of all atmospheric particles. Han et al. (2018) showed that secondary $\mathrm{SO}_{4}{ }^{2-}$ formation on polluted days had a strong 
correlation with the effect of $\mathrm{NO}_{2}$ on $\mathrm{SO}_{2}$ oxidation, while the oxidation effect of $\mathrm{O}_{3}$ was less important. Liu et al. (2015) also pointed out that meteorological factors, oxidants, and $\mathrm{pH}$ had an important influence on the formation of secondary $\mathrm{NO}_{3}{ }^{-}$and $\mathrm{SO}_{4}{ }^{2-}$

Nitrate in the atmosphere is mainly derived from the photochemical generation of $\mathrm{NO}_{2}$ and $\mathrm{OH} \cdot$ during the day and the heterogeneous hydrolysis of dinitrogen pentoxide $\left(\mathrm{N}_{2} \mathrm{O}_{5}\right)$ at night (Seinfeld, 2006). In recent years, the proportion of $\mathrm{NO}_{3}{ }^{-}$in $\mathrm{PM}_{2.5}$ during heavy pollution periods in China and the ratio of the $\mathrm{NO}_{3}{ }^{-}$and $\mathrm{SO}_{4}{ }^{2-}$ concentrations has been constantly increasing. Recent studies have shown that $\mathrm{NO}_{3}{ }^{-}$formationis mainly driven by the gasphase oxidation of $\mathrm{NO}_{\mathrm{x}}$. The oxidation of $\mathrm{OH} \cdot$ during the daytime contributes about $70-90 \%$ of atmospheric $\mathrm{NO}_{3}{ }^{-}$, and the oxidation of nitro radicals at nighttime contributes about $10-30 \%$. Due to the enhanced uptake of $\mathrm{NO}_{3}$ + volatile organic compounds $(\mathrm{VOCs})$ and $\mathrm{N}_{2} \mathrm{O}_{5}, \mathrm{NO}_{3}{ }^{-}$particle pollution has continued to increase in recent years and has exceeded that of $\mathrm{SO}_{4}{ }^{2-}$ (Wang, 2021b).Luo et al. (2020) reported that the level of $\mathrm{PM}_{2.5}$ pollution has an impact on the atmospheric accumulation of $\mathrm{NO}_{3}{ }^{-}$. In the cold season, when the $\mathrm{PM}_{2.5}$ concentration is less than $100 \mu \mathrm{gm}^{-3}$, with an increase in the $\mathrm{PM}_{2.5}$ concentration, the $\mathrm{NO}_{3}{ }^{-}$formation pathway gradually shifts from $\mathrm{NO}_{2}+\mathrm{OH} \cdot$ to $\mathrm{N}_{2} \mathrm{O}_{5}+\mathrm{H}_{2} \mathrm{O}$ and $\mathrm{NO}_{3}+\mathrm{VOCs}_{\text {. When the } \mathrm{PM}} \mathrm{W}_{2.5}$ concentration is greater than $100 \mu \mathrm{gm}^{-3}$, the $\mathrm{NO}_{3}{ }^{-}$formation pathway remains unchanged $\left(\mathrm{NO}_{2}+\mathrm{OH} \cdot\right)$.

In recent years, studies of the chemical components in atmospheric particulate matter in China have mainly been concentrated in the Beijing-TianjinHebei urban agglomeration, Yangtze River Delta, and Pearl River Delta urban agglomeration, with few studies conducted in northeast China. Zhang et al. (2020) speculated that the main source of aerosol particles that cause heavy haze pollution in northeast China is the accumulation of primary organic matter emitted from residential coal burning, with further deteriorations in air quality due to secondary aerosol formation via heterogeneous reactions. The second most important source was reported to be the long-range transport of agricultural biomass burning emissions. Hong et al. (2019) found that the growth rate of atmospheric $\mathrm{NO}_{3}{ }^{-}$concentrations exceeds that of $\mathrm{SO}_{4}{ }^{2-}$ during heavy haze weather, and is an important phenomenon during winter haze pollution in northeast China. The rapid generation of $\mathrm{SO}_{4}{ }^{2-}$ during haze is closely related to the aqueous reaction under high water vapor pressure. Nitrate homogeneous gas-phase reactions are an important feature of $\mathrm{NO}_{3}{ }^{-}$generation during haze pollution. Coal is the main fuel in northeast China. Unlike other areas of China, most of the local coal has a low-sulfur content. In addition, northeast China is the northernmost part of the country, and the winter is long and severely cold. The specific emissions and meteorological conditions of the region will have an impact on secondary particulate matter formation. In addition, monitoring stations are mainly located in big cities, with few observations in small cities, suburbs, and rural areas. It is therefore difficult to fully understand the mechanism of regional haze formation from the distribution of pollution sources, atmospheric physics, and chemical processes. Therefore, this study established 14 sampling sites in three different cities, and their suburbs and surrounding rural areas in northeast China to simultaneously observe the atmospheric $\mathrm{PM}_{10}$ and $\mathrm{PM}_{2.5}$ mass concentrations, their chemical components, and the precursor gas concentrations. The characteristics and production mechanisms of secondary particulate matter (i.e., $\mathrm{SO}_{4}{ }^{2-}$ and $\mathrm{NO}_{3}{ }^{-}$) under low-sulfur emission and low-T conditions has led to differences in the haze pollution process compared to other regions of China. The changes in secondary particulate matter concentrations due to meteorological factors and precursor gases, and the differences with other regions of China were investigated. The important role of the increase in the secondary particulate matter concentration during the formation of regional persistent haze pollution was also examined.

\section{Sampling And Analysis}

\subsection{Sampling and analysis}

A total of 14 sampling sites were set up in urban, suburban, and rural locations in northeast China. Simultaneous observations of $\mathrm{PM}_{10}$ and $\mathrm{PM}_{2.5}$ mass concentrations in winter were conducted from 2017 to 2019, and the chemical components of PM 2.5 were analyzed during the four most polluted periods. The detailed locations of each site are shown in Figure 1. The four episodes were: EP1 from December 26, 2017 to January 9,2018 (15 days); EP2 from December 10-17, 2018 (eight days); EP3 from January 10-15, 2019 (six days); and EP4 from February 13-4, 2019 (20 days). The four episodes lasted for a total of 49 days. The letters in the figure represent the 14 sampling sites. The urban sampling sites were Hashengtai Station in Harbin (HST); Beihai Station in Changchun (BH); Qianguo Station (QG), Daqing Station (DQ), Shenyang Station (SY), and Siju Station (SJ) in Harbin, DLS Station in Changchun (DLS), and Beilin Station (BL) and Yongji Station (YJ) in Jilin. The rural sites were BinXian Station (BX), Zhaodong Station (ZD), Yushu Station (YS), Siping Station (SP), and Gangzicun Station (GZC).

A Dandong Smart Medium Flow Sampler was used for $\mathrm{PM}_{2.5}$ sampling, with a flow rate of 28.3 $\mathrm{Lmin}^{-1}$. Whatman's quartz film was used to collect particle samples (Whatman, UK). The sampling frequency was once a day for $24 \mathrm{~h}$. The filter membrane was wrapped with tin foil before sampling and roasted in a muffle furnace at $550^{\circ} \mathrm{C}$ for $5 \mathrm{~h}$ to remove the residual organic matter and impurities. Before and after sampling, the quartz membrane was placed in a constant $\mathrm{T}$ and $\mathrm{RH}$ box $\left(50 \% \mathrm{RH}, 25^{\circ} \mathrm{C}\right)$ for $48 \mathrm{~h}$, weighed with a 100,000 balance (accurate to $\left.0.01 \mathrm{mg}\right)$, and the mass of the collected

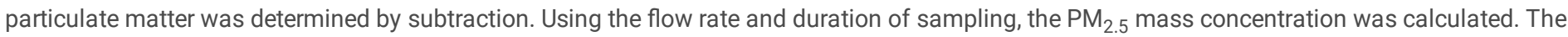
sample was stored in tin foil in a refrigerator $\left(-20^{\circ} \mathrm{C}\right)$ until analysis.

The chemical analysis included water-soluble ions $\left(\mathrm{F}^{-}, \mathrm{Cl}^{-}, \mathrm{NO}_{3}{ }^{-}, \mathrm{SO}_{4}{ }^{2-}, \mathrm{NH}_{4}{ }^{+}, \mathrm{Na}^{+}, \mathrm{K}^{+}, \mathrm{Ca}^{2+}\right.$, and $\left.\mathrm{Mg}^{2}\right)$ and $\mathrm{OC}$ and elemental carbon(EC). The detection limit of each ion was less than $0.003 \mathrm{mgL}^{-1}$. For the analysis, $1 / 4$ of the filter membrane was placed in $20 \mathrm{ml}$ ultrapure water (Millipore, USA, 18.2M $\Omega$ ) and treated three times in an ultrasonic bath. The extract was measured with ion chromatography(ICS2500 and ICS2000, Dionex, USA). The OC and EC 
analysis was conducted with a thermal/optical carbon analyzer (Sunset Laboratory Inc., USA). The CLEANOVEN program was run prior to the analysis to remove possible interferences in the instrument. To detect the amount of particulate organic carbon (POC)generated, the sample was irradiated with a $633 \mathrm{~nm}$ laser to measure the change in reflected light intensity during heating. The return of the reflection intensity was defined as the start point of the EC, and POC was isolated from EC1 to accurately determine the separation of OC and EC. Ultimately, the total OC of the particulate samples was defined as $\mathrm{OC}=\mathrm{OC} 1+\mathrm{OC} 2+\mathrm{OC} 3+\mathrm{OC} 4+\mathrm{POC}$, and $\mathrm{EC}$ was defined as $\mathrm{EC}=\mathrm{EC} 1+\mathrm{EC} 2+\mathrm{EC} 3-\mathrm{POC}$.

The $\mathrm{PM}_{10}, \mathrm{PM}_{2.5}, \mathrm{SO}_{2}, \mathrm{NO}_{2}, \mathrm{O}_{3}$, and $\mathrm{CO}$ data was collected from the Liaoning real-time air quality publishing system (http://211.137.19.74:8089/Home/RealTime).Meteorological data was obtained from the China Meteorological Administration Intranet CIMSS Data (http://10.86.121.55/cimissapiweb /apiwebuserinfo_toPersonalSpa.action).

\subsection{Quality control and quality assurance}

Quality control was performed in strict accordance with the relevant technical specifications. Blank samples were analyzed, and each analytical instrument was calibrated with standard materials. The correlation coefficient of the water-soluble ion calibration curve was not less than 0.995 , and the standard recovery rate was between $80 \%$ and $120 \%$. The OC/EC ratio was manually calibrated at the beginning and end of the daily analysis. The deviation in the corrected peak area was within $3.0 \%$, and was quantitatively calibrated with a $5 \% \mathrm{CH}_{4} / \mathrm{He}$ internal standard to ensure that it was within the quality control range. The correlation between manual sampling and online air monitoring results was significant $(P<0.05)$, and 14 instruments were compared in parallel before sampling to ensure that the results were accurate and comparable.

\section{Results And Discussion}

\subsection{Temporal changes of the pollution characteristics in four haze pollution episodes in northeast China during 2017-2019}

Table 1 and Figure 2 show the $\mathrm{PM}_{2.5}$ concentration $\left(\mu \mathrm{gm}^{-3}\right)$ and the concentrations of its chemical components during the sampling period at each sampling site. In EP3, only four sampling sites were analyzed, and they were not included in the calculation of total $\mathrm{PM}_{2.5}$. The $\mathrm{PM}_{2.5}$ concentration was $66.3-158.5 \mathrm{\mu gm}^{-3}$, with an average of $104.7 \mathrm{\mu gm}^{-3}$. This was 1.4 times China's national environmental standard $\left(24 \mathrm{~h}\right.$ average of $\left.75 \mu \mathrm{gm}{ }^{-3}\right)$ and 4.2 times the World Health Organization (WHO) standard $\left(\sim 25 \mu \mathrm{gm}^{-3}\right)$. The highest concentration was observed at HST, with the stations following the order of $\mathrm{HST}>\mathrm{BX}>\mathrm{SP}>\mathrm{SJ}>\mathrm{YS}>\mathrm{ZD}>\mathrm{DLS}>\mathrm{SY}>\mathrm{GZC}>\mathrm{BH}>\mathrm{BL}>\mathrm{DQ}>\mathrm{SY}>\mathrm{YJ}$. The $\mathrm{PM}_{2.5}$ concentrations were 158.5, 144.1, 129.8, 124.5, 122.9, 111.3, 95.8, 93.9, $91.5,90.8,84.7,77.3,74.3$, and $66.3 \mu \mathrm{gm}^{-3}$.

The chemical component concentrations at each sampling site were in the range of $52.4-109 \mu \mathrm{gm}^{-3}$, accounting for $63.8-82.1 \%$ of the $\mathrm{PM} 2.5$, with an average of $72 \%$ (Table 2). Total carbon (TC) was the component with the highest concentration $\left(31.2 \mu \mathrm{gm}^{-3}\right)$, accounting for $29.8 \%$ of the PM 2.5 . This was followed by water-soluble ions, with a concentration of $29.3 \mathrm{\mu gm}^{-3}$, accounting for $28 \%$ of the PM 2.5 . The winter heating period in northeast China has a duration of five months, and the large amounts of coal-fired emissions resulted in the contribution of organic matter to PM being much higher than in other seasons ( 30-40\%, Sun et al., 2013). Organic carbon (OC) was the most important component of $\mathrm{PM}_{2.5}$, with a concentration of $26.3 \mathrm{\mu gm}^{-3}$, followed by $\mathrm{NO}_{3}{ }^{-}$and $\mathrm{SO}_{4}{ }^{2-}$, with concentrations of 8.3 and $7.0 \mu \mathrm{gm}^{-3}$, respectively. Total carbon, $\mathrm{NO}_{3}{ }^{-}, \mathrm{SO}_{4}{ }^{2-}$, and $\mathrm{NH}_{4}{ }^{+}$accounted for $29.8 \%, 7.9 \%, 6.7 \%$, and $5.3 \%$, respectively, and in Beijing-Tianjin-Hebei accounted for $28 \%, 19 \%, 12 \%$, and $11 \%$, respectively, in the same time period (Wang, 2021a). The proportion of TC in $\mathrm{PM}_{2.5}$ in northeast China was higher than in the Beijing-Tianjin-Hebei region, but the other components had a lower proportional content. The absolute concentration and proportional content of $\mathrm{NO}_{3}{ }^{-}$in northeast China has surpassed that of $\mathrm{SO}_{4}{ }^{2-}$, and it has therefore become the most important secondary inorganic component of $\mathrm{PM}_{2.5}$. The rapid increase in the $\mathrm{NO}_{3}{ }^{-}$concentration during the pollution period has become one of the key factors in the explosive growth of $\mathrm{PM}_{2.5}$. The reason for this is the use of low-sulfur coal in the northeast. Low-sulfur coal reduces sulfur emissions and greatly reduces the overall concentration and proportional content of $\mathrm{SO}_{4}{ }^{2-}$ in $\mathrm{PM}_{2.5}$. In the winter the low Treduces the $\mathrm{pH}$ of $\mathrm{PM}_{2.5}$, which is conducive to $\mathrm{NO}_{3}{ }^{-}$production (Shi et al., 2019). The chemical component concentrations followed the order of $\mathrm{NH}_{4}{ }^{+}>\mathrm{EC}>\mathrm{Cl}-$ $>\mathrm{K}^{+}>\mathrm{Na}^{+}>\mathrm{Ca}^{2+}>\mathrm{Mg}^{2+}>\mathrm{F}^{-}$, with concentrations of $5.5,4.9,4.2,1.7,1.5,0.8,0.2$, and $0.1 \mu \mathrm{gm}^{-3}$ respectively. $\mathrm{SO}_{4}{ }^{2-}, \mathrm{NO}_{3}{ }^{-}$, and $\mathrm{NH}_{4}{ }^{+}(\mathrm{SNA})$ accounted for $19.9 \%$ of $\mathrm{PM}_{2.5}$ and $71 \%$ of total water-soluble ions. Organic matter and SNA were the main components of $\mathrm{PM}_{2.5}$. The main chemical components that contributed to haze pollution in northeast China were organic matter and inorganic water-soluble ions. These components were mainly derived from photochemical oxidation and the liquid-phase oxidation reactions of gaseous precursors. 
Table 1

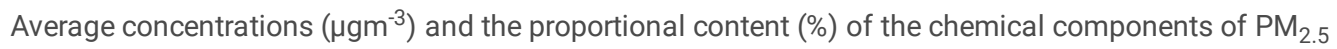

\begin{tabular}{|c|c|c|c|c|c|c|c|c|c|c|c|c|c|c|c|c|}
\hline & $\mathrm{PM}_{2.5}$ & $\mathrm{~F}^{-}$ & $\mathrm{Cl}^{-}$ & $\mathrm{NO}_{3}^{-}$ & $\mathrm{SO}_{4}{ }^{2-}$ & $\mathrm{Na}^{ \pm}$ & $\mathrm{NH}_{4}^{+}$ & $\mathbf{K}^{ \pm}$ & $\mathrm{Mg}^{2+}$ & $\mathrm{Ca}^{2+}$ & $O C$ & EC & TWSIs $^{*}$ & $\begin{array}{l}\text { TWSIs/ } \\
\text { PM }_{2.5}\end{array}$ & TC & $\begin{array}{l}\mathrm{TC} / \\
\mathrm{PM}_{2.5}\end{array}$ \\
\hline HST & 158.5 & 0.4 & 6.7 & 9 & 9.6 & 1.5 & 7.3 & 2.3 & 0.1 & 0.4 & 50.1 & 8.4 & 37.2 & 23.5 & 58.5 & 36.9 \\
\hline SJ & 124.5 & 0.1 & 4.7 & 9.5 & 7.7 & 1.6 & 6.5 & 2.2 & 0.1 & 0.5 & 34.3 & 6 & 32.9 & 26.4 & 40.3 & 32.4 \\
\hline$B X$ & 144.1 & 0.2 & 4.8 & 10.8 & 8.1 & 1.4 & 6.5 & 2.8 & 0.2 & 0.5 & 30.4 & 6.3 & 35.2 & 24.4 & 36.7 & 25.5 \\
\hline ZD & 111.3 & 0.1 & 4.4 & 6.2 & 7.1 & 1.4 & 4.6 & 2 & 0.1 & 0.9 & 28.5 & 4 & 26.8 & 24.1 & 32.5 & 29.2 \\
\hline $\mathrm{BL}$ & 84.7 & 0.1 & 1.7 & 4.1 & 4.5 & 1.7 & 2.8 & 1.2 & 0.1 & 0.4 & 28 & 7.9 & 16.6 & 19.6 & 35.9 & 42.4 \\
\hline $\mathrm{DQ}$ & 77.3 & 0.1 & 2.5 & 6.3 & 5.4 & 2.3 & 3.4 & 1 & 0.1 & 1.3 & 16.4 & 2.8 & 22.4 & 29 & 19.2 & 24.8 \\
\hline YJ & 66.3 & 0.1 & 2.6 & 5.3 & 5.8 & 2 & 3.7 & 1.5 & 0.1 & 1 & 15.6 & 2.5 & 22.1 & 33.3 & 18.1 & 27.3 \\
\hline $\mathrm{BH}$ & 90.8 & 0.1 & 4.1 & 9.4 & 6.5 & 1.3 & 5.9 & 1.5 & 0.1 & 0.6 & 20.9 & 3.4 & 29.5 & 32.4 & 24.3 & 26.7 \\
\hline GZC & 91.5 & 0.1 & 4.4 & 11.2 & 7.5 & 1.6 & 6.6 & 1.8 & 0.1 & 0.9 & 20.8 & 3.8 & 34.1 & 37.3 & 24.7 & 26.9 \\
\hline DLS & 95.8 & 0.1 & 5 & 9.3 & 7 & 1.2 & 4.8 & 1.1 & 0.8 & 1.8 & 21.4 & 6.2 & 31.1 & 32.4 & 27.6 & 28.9 \\
\hline SY & 74.3 & 0 & 3 & 4.2 & 4.5 & 0.9 & 3.2 & 1 & 0.1 & 0.4 & 16.8 & 4.2 & 17.3 & 23.3 & 21 & 28.3 \\
\hline YS & 122.9 & 0.1 & 5 & 8 & 6.2 & 1 & 6.1 & 1.7 & 0.1 & 1.2 & 31.7 & 5.3 & 29.5 & 24 & 36.9 & 30.1 \\
\hline $\mathrm{SP}$ & 129.8 & 0.1 & 6.4 & 11 & 7.7 & 1 & 7.2 & 2.4 & 0.1 & 0.2 & 35.4 & 4.8 & 36.1 & 27.8 & 40.2 & 31 \\
\hline SY & 93.9 & 0.1 & 4 & 12.5 & 9.7 & 1.8 & 8.3 & 1.3 & 0.3 & 1.1 & 18.6 & 2.9 & 39.1 & 41.6 & 21.5 & 22.9 \\
\hline average & 104.7 & 0.1 & 4.2 & 8.3 & 7 & 1.5 & 5.5 & 1.7 & 0.2 & 0.8 & 26.3 & 4.9 & 29.3 & 28 & 31.2 & 29.8 \\
\hline average/PM 2.5 & 100 & 0.1 & 4.0 & 7.9 & 6.7 & 1.4 & 5.3 & 1.6 & 0.2 & 0.8 & 25.1 & 4.7 & 28.0 & / & 29.8 & / \\
\hline
\end{tabular}

The common feature of the $\mathrm{PM}_{2.5}$ chemical component analysis was that the Harbin-centered area was more polluted than Changchun (Table 1 , Figure 3). Harbin and its nearby areas had the highest $\mathrm{OC}$ and $\mathrm{EC}$ levels, the $\mathrm{SO}_{4}{ }^{2-}$ and $\mathrm{NO}_{3}{ }^{-}$concentrations were highest in Shenyang, and the $\mathrm{K}^{+}$ concentration was higher in rural areas than in urban and suburban areas.

Table 2

The concentrations of $\mathrm{PM}_{2.5}$ and its chemical components in three pollution episodes $\left(\mu \mathrm{gm}^{-3}\right)$

\begin{tabular}{|lllllllllllll|}
\hline & $\mathrm{PM}_{2.5}$ & $\mathrm{~F}^{-}$ & $\mathrm{Cl}^{-}$ & $\mathrm{NO}_{3}{ }^{-}$ & $\mathbf{S O}_{4}{ }^{2-}$ & $\mathrm{Na}^{+}$ & $\mathbf{N H}_{4}^{+}$ & $\mathrm{K}^{+}$ & $\mathbf{M g}^{2+}$ & $\mathrm{Ca}^{2+}$ & $\mathrm{OC}$ & $\mathrm{EC}$ \\
\hline EP1 & 86.1 & 0.1 & 4.3 & 6.5 & 7.2 & 1.6 & 4.6 & 1.4 & 0.1 & 0.6 & 23.6 & 2.6 \\
\hline EP2 & 86.9 & 0.1 & 2.4 & 5.6 & 4.1 & 1.4 & 5.2 & 1.5 & 0.1 & 0.7 & 20.4 & 4.8 \\
\hline EP4 & 122.4 & 0.1 & 5.2 & 10.8 & 7.3 & 0.5 & 5.3 & 1.8 & 0.2 & 0.4 & 27.4 & 5.6 \\
\hline total & 98.5 & 0.1 & 3.9 & 7.6 & 6.2 & 1.2 & 5 & 1.5 & 0.1 & 0.6 & 23.8 & 4.3 \\
\hline
\end{tabular}

Comparing the three pollution episodes shown in Table 2, EP4 (in 2019) had the highest concentrations of PM 2.5 and its chemical components, while there was little difference between EP2(in 2018) and EP1(in 2017).

\subsection{The evolution of PM2.5 and its chemical composition and the causes of pollution during the fourth pollution episode}

Figure 4 shows the temporal changes of $\mathrm{PM}_{10}$ and $\mathrm{PM}_{2.5}$, their chemical components and precursor emission gas concentrations, meteorological factors, and the height of the boundary layer during the four pollution episodes. The evolution of EP1-EP4 in terms of the PM 2.5 concentration and its chemical composition, and the causes of pollution are analyzed below.

EP1 was formed by the combined effect of the accumulation of local coal emissions, secondary conversion under a low T and high RH, and regional transmission. Wind direction and wind speed were the primary meteorological factors that affected the pollutant concentration. The important indicators of the beginning and end of the pollution episodes was the change of wind direction and speed. Pollution started to accumulate on December 26, 2017, and when the wind direction changed to the southwest, $\mathrm{PM}_{2.5}$ concentrations increased in various locations. The PM 2.5 concentration peaked on January 1, 2018, when the wind speed was very low (Figures 4a, b; Figure 5). The wind turned to the north on January 1 , the 
wind speed increased, and the $\mathrm{PM}_{2.5}$ concentration decreased rapidly, with the pollution episode ending on January 9. Whenever the wind direction turned to the south and the wind speed decreased, the $\mathrm{PM}_{2.5}$ concentration gradually accumulated, but when the wind direction was northerly the wind speed increased and the concentration decreased rapidly (Figures 4 and 5). The trends of $\mathrm{SO}_{2}$ and $\mathrm{NO}_{2}$ were similar to those of $\mathrm{PM}$..5, indicating that emissions had a great impact on pollution. The $\mathrm{SO}_{2}$ and $\mathrm{NO}_{2}$ levels in EP1 were the highest of the entire three years. The boundary layer height (BLH) followed the opposite pattern to that of the pollution concentration (Figure 4x). A low BLH results in poor diffusion of pollutants and high pollutant concentrations, which plays an important role in the rise and fall of the pollutant concentration (Figure $4 \mathrm{v}$ ). The effects of air $\mathrm{T}$ and $\mathrm{RH}$ were also significant, and pollution in EP1 increased as the T increased (Figure 4p). However, the T on January 2-8 was higher than on the most polluted day December 31-January 1. It was apparent that T did not play a decisive role in pollution episodes. When the RH was high, the pollution was heaviest (Figure $4 \mathrm{w}$ ). A high $\mathrm{RH}$ was very important for pollution formation.

The $\mathrm{OC} / \mathrm{EC}$ ratio is used to characterize carbon aerosol emissions and conversion characteristics. Different ratios represent different sources of pollution. A ratio between 1.0 and 4.2 typically represents exhaust emissions from diesel and gasoline vehicles (Schauer et al., 2002); and a ratio of 2.5-10.5, represents emissions from coal combustion (He et al., 2004); while ratios of 9-12.3 and 16.8-40, represent biomass combustion emissions (Cao et al, 2005;Zhang et al.,2007). The average OC/EC ratio of the four episodes was 6.6 (1.5-25.6) (Figure 4s), indicating that they were all affected by secondary aerosol. Compared with the other three EPs, the OC/EC ratio was highest in EP1. The rural station SP had the highest OC/EC ratio, with a value exceeding 15 on six days. This was mainly due to the burning of rural straw. At the same time, the $\mathrm{K}^{+}, \mathrm{NH}_{4}{ }^{+}$, and $\mathrm{Cl}^{-}$concentrations, which were indicative of combustion emissions were also high, which indicates that they not all emissions were from straw combustion (Cao et al., 2010). The $\mathrm{OC} / \mathrm{EC}$ ratio at HST was between 5-12.5, indicating that the main source of its air pollution was emissions from coal combustion. The OC/EC ratios at the other stations were also largely in this range, indicating emissions from coal combustion.

The $\mathrm{SO}_{4}{ }^{2-}, \mathrm{NO}_{3}{ }^{-}$, and $\mathrm{NH}_{4}{ }^{+}$concentrations in $\mathrm{EP} 1$ were very high $\left(6.5,7.2\right.$, and $4.6 \mu \mathrm{gm}^{-3}$, respectively, Table 2$)$, with only the concentrations in EP4 being higher. The $\mathrm{SO}_{4}{ }^{2-}$ and $\mathrm{SO}_{2}$ concentrations, which were representative of coal burning, were higher than those of $\mathrm{NO}_{3}{ }^{-}$and $\mathrm{NO}_{2}$, indicating that the emissions from coal combustion were the most important factor in EP1 (Figures 4p,q, and r). The ratio of secondary pollutants (SNA) to EC is used to evaluate the degree of secondary conversion. The higher the value, the more serious the secondary pollution (Figure 4, Yang et al., 2018; Lin et al., 2009). Elemental carbon is usually considered to be a tracer of a pollution source. Comparing the ratio with the primary emissions $\left(\mathrm{Ca}^{2+}{ }^{+} \mathrm{Mg}^{2+}\right)$ and other components, if the primary emissions are high but the ratio is not high, the pollution is caused by the primary emissions, otherwise it is caused by secondary conversion or regional transmission. The $\mathrm{SO}_{4}{ }^{2-} / \mathrm{EC}$ and $\mathrm{NO}_{3}{ }^{-} / \mathrm{EC}$ ratios were lowest in EP3 among the four episodes, of which Shenyang and Siping had the highest values (>5). The $\mathrm{Ca}^{2+}$ and $\mathrm{Mg}^{2+}$ concentrations were not high, and therefore there were obvious regional transmission characteristics. At the other sampling sites, the $\mathrm{SO}_{4}{ }^{2-} / \mathrm{EC}$ and $\mathrm{NO}_{3}{ }^{-} / \mathrm{EC}$ ratios were very high, indicating that $\mathrm{SO}_{4}{ }^{2-}$ and $\mathrm{NO}_{3}{ }^{-}$were formed by secondary conversion. During the secondary conversion process, the T was low and RH was high. The SNA and OC concentrations increased and decreased with the rise and fall of RH (Figure 4). Ge et al. (2012) found that fog promoted the generation of secondary aerosols (SNA and oxidizing organic matter) in the atmosphere. A high $\mathrm{RH}$ is conducive to the absorption of the main chemical components in the moisture on the surface of $\mathrm{PM} \mathrm{M}_{2.5}$ and the pollutant concentration will then increase rapidly (see section 3.3 for details). Therefore, it was concluded that EP1 was a composite pollution process formed by local emissions from coal combustion, secondary conversion under a low $\mathrm{T}$ and high $\mathrm{RH}$, and regional transmission.

EP2 was expected to be dominated by straw burning pollutants due to the large-scale straw burning that occurred during the sampling process. The

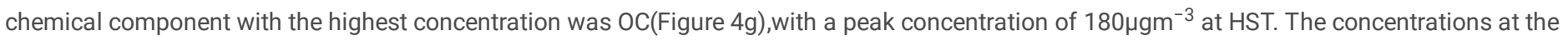
surrounding $\mathrm{BL}, \mathrm{BX}$, and SJ sites were also very high, indicating that straw burning made a significant contribution to OC. The most representative ion for straw burning is $\mathrm{K}^{+}$and its concentration was very high, with only EP4 having a higher concentration (Figure $4 \mathrm{~m}$ ). The $\mathrm{K}^{+}$concentrations at $\mathrm{HST}_{\text {, SJ, }}$ SP, BX, BL, and ZD were 5-7 times higher than the typical atmospheric concentration in the main straw burning area. The different sampling sites that were affected by straw burning displayed different characteristics. At HST and BX, OC and $\mathrm{K}^{+}$increased significantly at the same time, while the $\mathrm{K}^{+}$ concentration at SP increased more significantly than the $\mathrm{OC}$ concentration. There was a significant increase in $\mathrm{OC}$ at $\mathrm{BL}$, whereas $\mathrm{K}^{+}$did not increase significantly. These results may be related to the different local emission sources, with HST receiving a large contribution from straw combustion and motor vehicle emissions, SP being impacted by straw combustion, and BL being impacted by residential coal burning in the suburbs.

EP3 was a cross-regional transmission process. Figure 6a clearly shows the gradual reduction of PM 2.5 and other pollutants as they were transported from southwest to northeast. The jump point of the $\mathrm{PM}_{2.5}$ concentration changed from $\mathrm{SY} \rightarrow \mathrm{BH} \rightarrow \mathrm{SJ} \rightarrow \mathrm{HST}$ (Figure $6 \mathrm{~b}$ ), which indicated that EP3 was clearly dominated by a secondary transmission process. The $\mathrm{SO}_{4}{ }^{2-} / \mathrm{EC}$ and $\mathrm{NO}_{3}{ }^{-} / \mathrm{EC}$ ratios were the highest among the four pollution episodes, and the peak values of the four sampling sites were in the range of 6.7-18.9 (Figure 4p, q). This further confirms that the event was a regional transfer process.

EP4 was the pollution episode with the highest $\mathrm{PM}_{2.5}$ concentration and the heaviest pollution during the entire observation period. Its main features were a high $\mathrm{PM}_{2.5}$ and $\mathrm{O}_{3}$ concentration, and a high mid-winter $\mathrm{T}$. The $\mathrm{SO}_{2}$ and $\mathrm{NO}_{2}$ concentrations were lower than those of EP1 and EP3. The period was characterized by low emissions, and therefore the high levels of pollution were mainly a consequence of the strong oxidation conditions and high winter T. 
There were three pollution peaks in EP4 (Figure 4), with high concentrations of the main chemical components (OC and SNA). The first peak was on February 15. The $\mathrm{PM}_{10}$ concentration was highest at $\mathrm{BX}$ and $\mathrm{YS}$, which were the representative rural sampling sites, and it was much higher than the $\mathrm{PM}_{2.5}$ concentration (Figure 4), indicating that there was a large proportion of coarse particles. However, the $\mathrm{NO}_{3}{ }^{-} / \mathrm{EC}$ and $\mathrm{SO}_{4}{ }^{2-} / \mathrm{EC}$ ratios were not very high, indicating that primary pollutants were the major contributors to the pollutant load. The $\mathrm{BX}$ site had the highest $\mathrm{SO}_{4}{ }^{2-}$ and $\mathrm{CO}^{-}$ concentrations, as well as high concentrations of $\mathrm{NO}_{2}$. OC, $\mathrm{EC}, \mathrm{Cl}-, \mathrm{NO}_{3}{ }^{-}, \mathrm{NH}_{4}{ }^{+}$, and $\mathrm{K}^{+}$and other coal-burning emission index ions $(\mathrm{Wang}$ et al., $2021 \mathrm{a}$; Hu et al., 2015). The YS site also had high concentrations of chemical components. These sites were located in rural areas, with few motor vehicles, and the high concentrations were likely caused by high emissions of loose coal and biomass combustion.

The second peak occurred on February 21. The wind direction at each station was southerly. The PM 2.5 concentration at BX, HST, and SJ was high (Figure $4 \mathrm{~b}$ ), the weather conditions were stable, and the wind speed was low to calm(i.e., less than $2 \mathrm{~m} / \mathrm{s}$ ) (Figure 5). The T continued to increase and

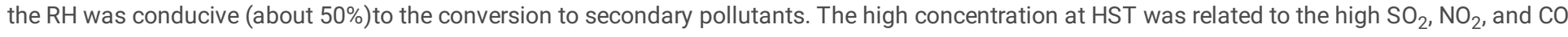
emissions on the previous day. On February 20th in $\mathrm{BX}$, the $\mathrm{NO}_{3}{ }^{-}$and $\mathrm{SO}_{4}{ }^{2-}$ concentrations were high, the OC concentration at $\mathrm{SJ}$ was high, and the EC concentration at BX and SJ was high. These results indicated the secondary generation of local coal emissions under suitable $\mathrm{T}$ and $\mathrm{RH}$ conditions in a small area. The pollution process occurred under the joint action of atmospheric diffusion (see section 3.3 for details).

The $\mathrm{PM}_{2.5}$ concentration in the third peak was the highest during the entire observation period. There were three main reasons for this.

$\triangle$ The photochemical generation of high levels of secondary organic carbon (SOC). The high levels of SOC (Figure 4t, estimated by the OC/EC minimum ratio method, $\mathrm{SOC}=\mathrm{OC}-\mathrm{EC} \times(\mathrm{OC} / \mathrm{EC}) \mathrm{min}$. Li et al., 2018a)accounted for the highest proportion of OC (Figure $4 \mathrm{u})$. The $\mathrm{O}_{3}$ concentration and $\mathrm{T}$ were also the highest during the entire observation period (Figure $4 \mathrm{e}$ and $\mathrm{v}$ ). The high $\mathrm{O}_{3}$ concentration enhances the atmospheric oxidability, which coupled with the high T, was conducive to SOC formation. Li (2018a) and Hu et al. (2012) in Zibo and the Pearl River Delta both found that SOC and $\mathrm{O}_{3}$ increased in a similar manner.

\A large amount of secondary generation of SNA. The SNA concentration was only higher in EP3 due to regional transmission. However, the $\mathrm{SO}_{2}$ concentration was the lowest among the four pollution episodes, and the $\mathrm{NO}_{2}$ concentration was the same as in EP1. Due to the low emission levels, the high pollution load was created by high secondary pollutant concentrations. There were two main reasons for this. First, under a relatively high $\mathrm{T}$ $\left(0-5^{\circ} \mathrm{C}\right)$ and $\mathrm{RH}(40-60 \%)$, which was not high enough to limit the reaction, the gas emitted by local coal and motor vehicles generated a high SNA concentration through homogeneous and heterogeneous phase reactions (see section 3.3 for details).

Similarly, SJ, HST, DQ, ZD, and SY had high $\mathrm{PM}_{2.5}$ concentrations, which may be related to their higher local emissions. The OC, EC, and $\mathrm{Cl}^{-}$ concentrations at SJ and ZD were high on February 26-28, the OC and EC concentrations at DQ and HST were high on February 28, and the SNA concentration at SY had been continuously increasing since February 27 . This indicates that the peaks were mainly the local secondary conversion of primary emissions. At this time, the $\mathrm{SO}_{4}{ }^{2-}$ concentration was high (Figure $4 \mathrm{k}$, peak value $6.1-20.4 \mu \mathrm{gm}^{-3}$ ), but still lower than the $\mathrm{NO}_{3}{ }^{-}$concentration. The $\mathrm{NO}_{3}{ }^{-} / \mathrm{SO}_{4}{ }^{2-}$ ratio was mostly $>1$, with the highest value reaching 2.5 (Figure $4 \mathrm{r}$ ).

The reason why the $\mathrm{NO}_{3}{ }^{-}$concentration was higher than the $\mathrm{SO}_{4}{ }^{2-}$ concentration was related to the low $\mathrm{SO}_{2}$ emission concentration, which limited $\mathrm{SO}_{4}{ }^{2-}$ formation. It may also be related to the high $\mathrm{O}_{3}$ concentration and the strong gas oxidation was conducive to the gas-particle conversion of $\mathrm{NO}_{3}{ }^{-}$. The high $\mathrm{O}_{3}$ concentration had an important effect on $\mathrm{NO}_{3}{ }^{-}$and $\mathrm{SO}_{4}{ }^{2-}$ formation. Studies have found that under suitable light conditions, the

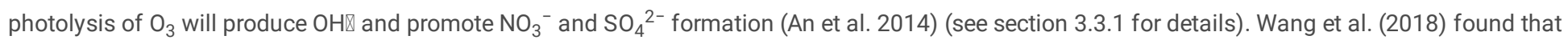
the low $\mathrm{T}$ of urban high-rise buildings and the high $\mathrm{O}_{3}$ concentration in the residual layer at night can promote the gas-particle conversion of $\mathrm{NO}_{3}{ }^{-}$and the heterogeneous reaction of $\mathrm{N}_{2} \mathrm{O}_{5}$. In this study, $\mathrm{NO}_{3}{ }^{-}$formation was dependent on the combination of a high $\mathrm{T}$ in winter and a high $\mathrm{O}_{3}$ concentration. This involved the formation of low-T gas-particles at night, and the formation of high-T photochemical reactions during the day. It can be seen that the increase in the $\mathrm{O}_{3}$ concentration greatly increased the $\mathrm{NO}_{3}{ }^{-}$and $\mathrm{SO}_{4}{ }^{2-}$ concentration, and it is therefore very important to strengthen the control of $\mathrm{O}_{3}$ and $\mathrm{NO}_{x}$ pollution.

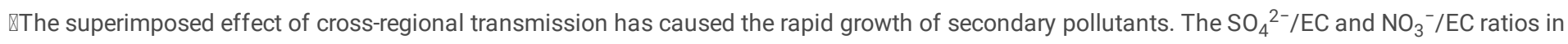
Figure $4 \mathrm{q}$ and $\mathrm{r}$ are very high, indicating that secondary formation occurs through the superimposition of regional transport and secondary reactions. The OC/EC ratio was not high (Figure4s, between 1.7 and 8.4, with an average of 4.9), indicating that it was mainly controlled by emissions from coal combustion and motor vehicle exhaust emissions. It can be seen from the graphs of the $\mathrm{PM}_{2.5}$ concentration and wind field in Figure 7 that the most polluted area was near Harbin (HST). At this time, the wind direction and wind speed of each station changed from northerly to southerly, and the wind speed decreased rapidly. This shows that the atmosphere was in a static and stable state, and the static and stable meteorological conditions were also conducive to the accumulation of secondary particulate matter. In addition, the wind field at the high-concentration center of the BL site had an obvious counterclockwise convergence, and the wind speed was higher than that in the surrounding areas, which accelerated the accumulation of pollutants at the site. 
It can be seen that EP4 was a compound pollution process. The $\mathrm{Cl}^{-}$and $\mathrm{OC}$ concentrations were the highest among the four episodes, indicating that coal combustion made a substantial contribution, and the $\mathrm{K}^{+}$and $\mathrm{Mg}^{2+}$ concentrations were also the highest among the four episodes. Biomass combustion and industrial emissions also made a large contribution. Except for the high $\mathrm{Ca}^{2+}$ concentrationatthe BX and ZD sites on February 21 st, the levels at the other stations were low. The main source of $\mathrm{Ca}^{2+}$ is usually sand and dust emissions (Xu et al., 2017b), indicating that the impact of sand and dust was small in EP4. Therefore, the pollution formation during this episode occurred through the homogeneous and heterogeneous reaction of pollutants emitted by local coal combustion, biomass combustion $\left(\mathrm{K}^{+}\right)$, and industrial emissions $\left(\mathrm{Mg}^{2+}\right)$ under a moderate $\mathrm{T}$ and strong gas oxidizing conditions (high $\mathrm{O}_{3}$ ). It was formed by a significant increase in the secondary pollutant concentrations, such as SOC and SNA, and then superimposed on a composite pollution process controlled by regional transmission.

\subsection{The influence of meteorological factors (e.g., $\mathrm{T}$ and $\mathrm{RH})$ on secondary pollutant $\left(\mathrm{SO}_{4}{ }^{2-}\right.$ and $\mathrm{NO}_{3}{ }^{-}$) formation in the haze pollution process}

\subsubsection{Nitrate formation}

The rapid increase in secondary pollutant $\left(\mathrm{SO}_{4}{ }^{2-}\right.$ and $\left.\mathrm{NO}_{3}{ }^{-}\right)$concentrations is an important reason for haze formation, and meteorological factors also play an important role in secondary pollutant formation.

Nitrate formation in the northeastern urban agglomeration was investigated. The relationship between $\left[\mathrm{NH}_{4}{ }^{+}\right]_{\text {excess }}$ and $\mathrm{NH}_{4}{ }^{+} / \mathrm{SO}_{4}{ }^{2-}(\mathrm{molar}$ concentration ratio; Pathak et al., 2009) was used to determine the occurrence of $\mathrm{NO}_{3}{ }^{-}$under different pollution processes and different weather conditions, and homogeneous and heterogeneous chemical reactions. The $\left[\mathrm{NH}_{4}{ }^{+}\right]_{\text {excess }}=\left(\left(\mathrm{NH}_{4}{ }^{+} / \mathrm{SO}_{4}{ }^{2-}-1.5\right) \times\left[\mathrm{SO}_{4}{ }^{2-}\right]\right)$ was calculated during the entire observation period. Figure 8 shows its correlation with $\mathrm{NO}_{3}{ }^{-}$. During the pollution process, $\mathrm{NO}_{3}{ }^{-}$and $\left[\mathrm{NH}_{4}{ }^{+}\right]_{\text {excess }}$ had a strong linear relationship $\left(\mathrm{R}^{2}=0.81\right)$, indicating that $\mathrm{NO}_{3}{ }^{-}$was mainly generated through heterogeneous reactions (Pathak et al., 2005)). The $\mathrm{NO}_{3}{ }^{-}$concentration increased with the increase in $\left(\left[\mathrm{NH}_{4}{ }^{+}\right]_{\text {excess }}\right.$ (Figure 8a). Therefore, the $\mathrm{NO}_{3}{ }^{-}$formationin the northeastern urban agglomeration occurred mainly through the homogeneous gas-phase reaction of atmospheric ammonia $\left(\mathrm{NH}_{3}\right)$ and nitric acid $\left(\mathrm{HNO}_{3}\right)$.

The $\mathrm{NO}_{3}{ }^{-}$formation conditions and accumulation mechanisms differ under the influence of different emission and meteorological factors. In recent years, the $\mathrm{NO}_{x}$ concentration was often higher than that of $\mathrm{SO}_{2}$. The low slope value of Figure $8 \mathrm{a}(0.62)$ indicates that the $\mathrm{NH}_{4}{ }^{+}$concentration in northeast China was much higher than that of $\mathrm{NO}_{3}{ }^{-}$, which was conducive to $\mathrm{NO}_{3}{ }^{-}$formation. Because emissions from coal combustion make a large contribution to atmospheric $\mathrm{NH}_{4}{ }^{+}$and $\mathrm{Cl}^{-}$(Xu et al., 2017b), the $\mathrm{Cl}^{-}$concentration was added to evaluate the relationship between [ $\left.\mathrm{NH}_{4}{ }^{+}\right]_{\text {excess }}$ and $\mathrm{NO}_{3}{ }^{-}$(Figure 8b). The correlation coefficients for the relationships between $\left[\mathrm{NH}_{4}{ }^{+}\right]_{\text {excess }}$ and $\mathrm{NO}_{3}{ }^{-}+\mathrm{Cl}^{-}$in all pollution processes were greater than 0.82 , and for EP4 the value was 0.99. The slope was also very high, indicating that after $\mathrm{NH}_{4}{ }^{+}$neutralized all of the $\mathrm{NO}_{3}{ }^{-}$and $\mathrm{SO}_{4}{ }^{2-}($ forming ammonium nitrate $\left(\mathrm{NH}_{4} \mathrm{NO}_{3}\right)$ and ammonium sulfate $\left.\left(\left(\mathrm{NH}_{4}\right)_{2} \mathrm{SO}_{4}\right)\right)$, there may be a surplus, which would continue to react with $\mathrm{Cl}^{-}$and other anions, mainly in the form of ammonium chloride $\left(\mathrm{NH}_{4} \mathrm{Cl}\right)$. In EP1 and EP4, the slopes were 1.1 and 1.14, and the intercepts were 0.09 and 0.12 , respectively, indicating that some of the $\mathrm{NO}_{3}{ }^{-}+\mathrm{Cl}^{-}$was not completely neutralized by $\mathrm{NH}_{4}{ }^{+}$. In Figure $4 \mathrm{n}$, it can be seen that the Ca ${ }^{2+}$ concentration in EP1 was higher than in the other pollution episodes, and the contribution of sand dust was also greater. The remaining $\mathrm{NO}_{3}{ }^{-}$and $\mathrm{Cl}^{-}$may exist in the form of calcium nitrate $\left(\mathrm{Ca}\left(\mathrm{NO}_{3}\right)_{2}\right)$ and calcium chloride $\left(\mathrm{CaCl}_{2}\right)$. The lowest slope of EP2 was 0.68 , indicating that after all the $\mathrm{NO}_{3}{ }^{-}+\mathrm{Cl}^{-}$was neutralized, there was still a large amount of $\mathrm{NH}_{4}^{+}$. The main feature of EP2 was that straw burning produced a large amount of $\mathrm{NH}_{3}$, and therefore the $\mathrm{NH}_{4}{ }^{+}$concentration was also high. The slope of EP3 was 1.04, indicating that $\mathrm{NH}_{4}{ }^{+}$was present in excess and $\mathrm{Cl}$ - emissions from coal combustion were not high. The $\mathrm{K}^{+}$ concentration in EP4 was high. The contribution of biomass combustion was also high, which may have enabled potassium to exist in the form of potassium nitrate $\left(\mathrm{KNO}_{3}\right)$ and potassium chloride $(\mathrm{KCl})$.

Nitrate in the EP1 process was formed under the conditions of a medium $\mathrm{T}$ and high $\mathrm{RH}$. At this time, the warming period in winter was occurring (Figure 8d, 5v), and the $\mathrm{RH}$ was also high when $\mathrm{NO}_{3}{ }^{-}$peaked (Figure $8 \mathrm{c}, 5 \mathrm{w}$ ). This shows that $\mathrm{NO}_{3}{ }^{-}$formation occurred when the $\mathrm{T}$ was mild in winter and the $\mathrm{RH}$ was high. A high $\mathrm{T}$ was conducive to the homogeneous gas-phase reaction of $\mathrm{NO}_{2}$ reacting with $\mathrm{OH} \otimes$ to produce gaseous $\mathrm{HNO}(\mathrm{Harris}$ et al., 2013). A T not higher than $4^{\circ} \mathrm{C}$ is also conducive to $\mathrm{NO}_{3}{ }^{-}$formation. The reaction therefore proceeded in the positive direction (Sun et al., 2012). The subsequent reaction between gaseous $\mathrm{HNO}_{3}$ and $\mathrm{NH}_{3}$ needs to occur at a higher $\mathrm{RH}$, because although $\mathrm{NO}_{3}{ }^{-}$is mainly formed through a homogeneous reaction in the gas-phase, a high $\mathrm{RH}$ is conducive to the accumulation of $\mathrm{NO}_{3}{ }^{-}$in the particles (Shi et al., 2014). Therefore, a high $\mathrm{RH}$ promotes $\mathrm{NO}_{3}{ }^{-}$formation.

The EP2 process was clearly impacted by straw burning emissions, with rapid $\mathrm{NO}_{3}{ }^{-}$formation in an $\mathrm{NH}_{3}$-rich environment. Straw burning in the vicinity of several cities, coupled with southerly winds, was conducive to the spread of pollution from south to north. In particular, the wind speeds at several sampling sites were high on December 15 (Figure 5, 4-5ms ${ }^{-1}$ ), which caused pollution to rapidly spread to the area. On the December16 the wind speed decreased rapidly, and the calm winds were conducive to the accumulation of pollutants. At this time, at SP, YS, and other locations, the RH was high $(40-60 \%$, Figures $4 \mathrm{w}$ and $8 \mathrm{c})$, and the $\mathrm{T}$ was low $\left(-15\right.$ to $-11^{\circ} \mathrm{C}$, Figure $\left.4 \mathrm{v}\right)$, and therefore straw burning pollutants accumulate in wet weather conditions to produce haze. There are records of haze in various locations. 
In the EP3 pollution process, the $\mathrm{NO}_{3}{ }^{-}$concentration was the highest among the four pollution episodes (Figure 4j, Figure 9a). It was formed by the secondary pollutants in the high $\mathrm{RH}$ and medium T environment during the transmission process, and the RH has a great influence on it. The RH was also the highest of the four periods at around 50-80\% (Figures $9 \mathrm{a}, \mathrm{c}$ and Figure $4 \mathrm{w}$ ), and the T was centered at $-10-0^{\circ} \mathrm{C}(\mathrm{Figure} 4 \mathrm{v}$ ).

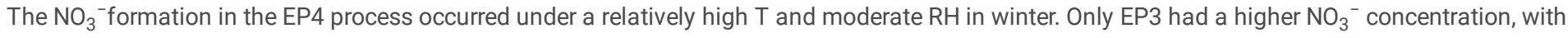
the $\mathrm{NO}_{3}{ }^{-}$concentration in the third peak period being especially high (Figures $4 \mathrm{j}, 9 \mathrm{a}$ ). The $\mathrm{RH}$ was only between $40-60 \%$ (Figures $4 \mathrm{w}$, and $8 \mathrm{a}$, $\mathrm{c}$ ). Although the $\mathrm{RH}$ was not high, the deliquescent $\mathrm{RH}$ of the particulate matter was still higher than the weathered $\mathrm{RH}$, which caused it to continue to deliquesce without being weathered, and a high water content was maintained in the particulate matter. In conjunction with the high winter $\mathrm{T}$ and strong atmospheric oxidability, serious haze pollution could still occur. The pollution concentration sometimes exceeded the concentration recorded when the $\mathrm{RH}$ was higher and the T was lower (such as in EP1). It can be seen that the influence of $\mathrm{RH}_{\text {on }} \mathrm{NO}_{3}{ }^{-}$in northeast China was not as obvious as its influence on $\mathrm{SO}_{4}{ }^{2-}$. Li et al. (2017), Sun et al. (2013), and Wang et al. (2014) also reached similar conclusions in a study of pollution in the Beijing-Tianjin-Hebei region. Wang et al. (2014) estimated that the influence of fog was responsible of $70 \%$ of the $\mathrm{SO}_{4}{ }^{2-}$ formation in winter in Beijing, while the impact on $\mathrm{NO}_{3}{ }^{-}$was less than $30 \%$. Under the condition where a certain $\mathrm{RH}$ was maintained, a higher $\mathrm{T}$ was more conducive to the homogeneous reactions involved in $\mathrm{NO}_{3}{ }^{-}$formation.

In the EP4 process $\mathrm{T}$ conditions were very favorable, with the highest Ts recorded during all observations (between -4 and $-2^{\circ} \mathrm{C}$, Figure $8 \mathrm{a}$, d). A higher $\mathrm{T}$

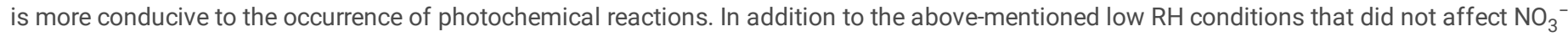
formation and the warmer T conditions in winter, the oxidative properties of the atmosphere were also important for $\mathrm{HNO}_{3}$ formation. During $\mathrm{EP}_{4}$, there were high $\mathrm{O}_{3}$ concentrations (Figure $4 \mathrm{e}$ ), and nitrous acid (HONO) peaks also appeared at the same time as the first two peaks of $\mathrm{NO}_{3}{ }^{-}(\mathrm{Figure} 9 \mathrm{~b})$. The $\mathrm{SO}_{4}{ }^{2-}, \mathrm{NO}_{3}{ }^{-}, \mathrm{HONO}, \mathrm{HNO}_{3}$, and $\mathrm{NH}_{3}$ concentrations in Figure 10 were measured by the Marga instrument in the Shenyang Atmospheric Composition Station. At this time, $\mathrm{NO}_{3}{ }^{-}$and $\mathrm{SO}_{4}{ }^{2-}$ formation occurred through the gas-phase oxidation reactions of $\mathrm{OH} \cdot$ with $\mathrm{NO}_{2}$ and $\mathrm{SO}_{2}$, respectively $(\mathrm{Seinfeld}$ and Pandis, 2006). The main sources of $\mathrm{OH}$ - were the photolysis of $\mathrm{O}_{3}$ and $\mathrm{HONO}$ (Ji et al., 2016). Although the scattering, reflection, and refraction of haze pollution in winter will weaken the amount of solar radiation reaching the ground and affect the generation of $\mathrm{OH}$; high $\mathrm{HONO}$ concentrations can produce large amounts of $\mathrm{OH} \cdot$ under suitable light conditions, ensuring the uniform progress of the homogenous $\mathrm{NO}_{3}{ }^{-}$formation reaction. During the daytime, $\mathrm{HONO}$ photolysis produces $\mathrm{OH} \cdot \mathrm{OH}$. reacts with $\mathrm{VOC}$ and $\mathrm{NOx}$ in a multi-chain reaction, and this increases the $\mathrm{O}_{3}$ concentration. The $\mathrm{O}_{3}$ further promotes $\mathrm{OH}$. production through photolysis, and $\mathrm{OH}$. continues to oxidize $\mathrm{NO}_{2}$ and $\mathrm{SO}_{2}$, which promotes $\mathrm{HNO}_{3}$ and $\mathrm{SO}_{4}{ }^{2-}$ formation $(\mathrm{An}$ et al. 2014). The reaction rate is related to the amount of liquid water adsorbed on the particle-air interface. Strong correlations have been reported between aerosol and HONO concentrations, and the specific surface area of an aerosol and the HONO concentration (Finlayson-Pitts et al., 2003). Part of the reaction product is separated from $\mathrm{HONO}$ when the reaction surface returns to the atmosphere, while $\mathrm{HNO}_{3}$ stays on the reaction surface and reparticipates in a series of atmospheric chemical reactions, increasing the $\mathrm{NO}_{3}{ }^{-}$concentration in the atmosphere. Therefore, the high atmospheric oxidability formed by the high $\mathrm{O}_{3}$ and $\mathrm{HONO}$ concentrations in the EP4 process promoted photochemical reactions and produced a large amount of $\mathrm{NO}_{3}{ }^{-}$.

Similarly, during EP4, a high $\mathrm{NH}_{3}$ concentration was observed, which reacted with $\mathrm{HNO}_{3}$ (Figure 9b) and promoted massive $\mathrm{NO}_{3}{ }^{-}$aerosol formation. Due to the use of low-sulfur coal and the widespread use of desulfurized rubber as pollution control measures, $\mathrm{SO}_{2}$ concentrations have decreased, but $\mathrm{NH}_{3}$ emissions have risen at the same time. The $\mathrm{NO}_{3}{ }^{-}$concentration increased significantly with the increased $\mathrm{NH}_{3}$ emissions $($ Figure 9 a). The relatively warm $\mathrm{T}\left(-4\right.$ to $\left.-2^{\circ} \mathrm{C}\right)$ was conducive to an acceleration of the neutralization reaction of $\mathrm{NH}_{3}$ and $\mathrm{HNO}_{3}$, which promoted $\mathrm{NO}_{3}{ }^{-}$formation. $\mathrm{Many}^{-}$ studies have also shown that a sufficient source of $\mathrm{NH}_{3}$ will effectively promote $\mathrm{NO}_{3}{ }^{-}$and $\mathrm{SO}_{4}{ }^{2-}$ particulate formation, resulting in the rapid accumulation of particulate matter (2015; Guo et al., 2017). A high $\mathrm{NH}_{3}$ concentration promotes $\mathrm{NO}_{3}{ }^{-}$aerosol formation in a ubiquitous atmospheric chemical phenomenon that has also been observed in other cities in northern China (Sun et al., 2018). In addition, under a high $\mathrm{RH}$ and rich $\mathrm{NH}_{3}$ conditions, $\mathrm{SO}_{4}{ }^{2-}$ will also be generated in large quantities. The $\mathrm{pH}$ of the aerosol surface is close to 7 , and $\mathrm{NO}_{2}$ oxidizes $\mathrm{SO}_{2}$ to generate $\mathrm{SO}_{4}{ }^{2-}(\mathrm{Wang}$

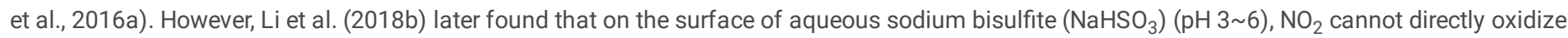
$\mathrm{S}(\mathrm{IV})$ to form $\mathrm{SO}_{4}{ }^{2-}$, but instead generates $\mathrm{NO}_{3}{ }^{-}$and HONO. Based on this analysis, the possibility of HONO oxidation of $\mathrm{S}(\mathrm{IV})$ is a more important mechanism of $\mathrm{NO}_{3}{ }^{-}$formation. In this study, the $\mathrm{NO}_{3}{ }^{-}$formation in northeastern China was mainly due to the mild $\mathrm{T}$, high $\mathrm{RH}$, high atmospheric oxidability $\left(\mathrm{O}_{3}\right.$ and $\left.\mathrm{HONO}\right)$, suitable light conditions, and a high $\mathrm{NH}_{3}$ concentration. A homogeneous gas-phase reaction occurred between $\mathrm{OH} \cdot$ and $\mathrm{NO}_{2}, \mathrm{SO}_{2}$, and $\mathrm{NH}_{3}$.

\subsubsection{The relationship between the $\mathrm{SO}_{4}{ }^{2-}$ concentration and water vapor pressure}

To characterize the relationship between ion concentrations and $\mathrm{RH}$, the relationship between ambient water vapor pressure( $\mathrm{e}^{\star}$ ) and the $\mathrm{SO}_{4}{ }^{2-}$ concentration was determined for different pollution periods, under different $\mathrm{RH}$, $\mathrm{T}$, and sulfur oxidation rate (SOR) conditions, and with different precursor gas concentrations (mainly $\mathrm{SO}_{2}$ and $\mathrm{NO}_{2}$ ). The ambient water vapor pressure was calculated using the formula $\mathrm{e}^{\star}=\mathrm{e} \times \mathrm{RH} / 100(\mathrm{e}$ refers to the saturated water vapor pressure, where $\mathrm{e}=6.112 \mathrm{exp}\left(17.67 \mathrm{t} /(\mathrm{t}+243.5)\right.$, $\mathrm{t}$ refers to the $\left.\mathrm{T}\left({ }^{\circ} \mathrm{C}\right)\right)$. The SOR refers to the molar ratio of sulfur in $\mathrm{SO}_{4}{ }^{2-}$ to the 


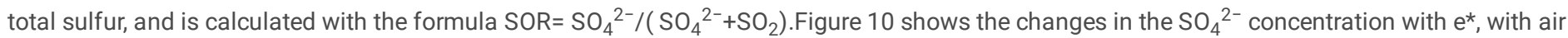
temperature, different pollution periods, $\mathrm{RH}$, and the precursor gases shown in different colors.

The trend of the fitted line in Figure $10 \mathrm{a}$ shows that $\mathrm{SO}_{4}{ }^{2-}$ increased with an increase in $\mathrm{e}^{\star}$, but the increase was not very obvious, indicating that $\mathrm{SO}_{4}{ }^{2-}$ formation was complicated. Taking $\mathrm{e}^{\star}=1.5$ and the $\mathrm{SO}_{4}{ }^{2-}$ concentration $=10 \mu \mathrm{gm}^{-3}$ as boundaries, the figure could be divided into four areas. Figure 11 shows the statistical values of various pollutants, $\mathrm{T}$, and $\mathrm{RH}$ in the four areas.

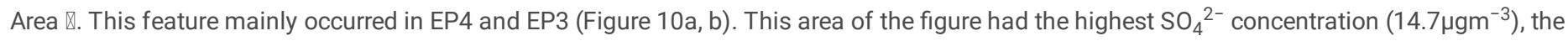
highest $\mathrm{T}_{\text {and }} \mathrm{O}_{3}\left(3.7^{\circ} \mathrm{C}\right.$ and $71.6 \mu \mathrm{gm}^{-3}$,Figure 10a, Figure 11), coupled with high $\mathrm{HONO}$ and $\mathrm{NH}_{3}$ concentrations (Figure 9b). The degree of oxidation of $\mathrm{NO}_{2}$ and $\mathrm{SO}_{2}$ was enhanced, and the SOR $(0.3$, Figure $10 \mathrm{~d}), \mathrm{SO}_{4}{ }^{2-}\left(14.7 \mu \mathrm{gm}^{-3}\right)$, and $\mathrm{NO}_{3}{ }^{-}\left(22.3 \mu \mathrm{gm}^{-3}\right)$ increased the most. Although the SO concentration was low, the $\mathrm{NO}_{2}$ concentration was high, and the prevailing conditions still supported $\mathrm{SO}_{4}{ }^{2-}$ formation. At the same time, the $\mathrm{RH}$ was not high (Figure 10d, Figure 11,63.8\%), which affected the aqueous phase reaction of $\mathrm{SO}_{4}{ }^{2-}$ to a certain extent. In area $\mathbb{X}$, the correlation between SOR and $\mathrm{O}_{3}$ was highest $(0.473$, Table 3$)$, and the correlation with $\mathrm{T}(0.275)$ was higher than the correlation with $\mathrm{RH}(0.110)$,

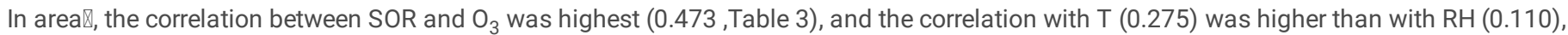
indicating that $\mathrm{SO}_{4}{ }^{2-}$ was mainly transformed by the $\mathrm{SO}_{2}$ gas-phase instead of aqueous oxidation. Therefore, the $\mathrm{SO}_{4}{ }^{2-}$ formation in area $\varangle$ was mainly the homogeneous gas-phase reaction of the $\mathrm{OH}$ - oxidation of $\mathrm{NO}_{2}$ and $\mathrm{SO}_{2}$. The source of $\mathrm{OH} \cdot$ was the photolysis of $\mathrm{O}_{3}$ and $\mathrm{HONO}$, which plays a key role in atmospheric chemistry ( $\mathrm{Ji}$ et al., 2016). The oxidation rate of $\mathrm{OH}$. is usually several times or even hundreds of times higher than in other pathways (Tang et al., 2006). Many studies have shown that the gas-phase oxidation of $\mathrm{SO}_{2}$ by $\mathrm{OH}$ - and peroxyl radicals is important for $\mathrm{SO}_{4}{ }^{2-}$ formation (Xie et al., 2009). Therefore, the photochemical activity had a very important influence on the gas-phase conversion of $\mathrm{SO}_{2}$ to $\mathrm{SO}_{4}{ }^{2-}{ }^{-}$during the haze events. Previous studies have shown that the heterogeneous chemical reaction of $\mathrm{SO}_{4}{ }^{2-}$ is an important pathway for $\mathrm{SO}_{4}{ }^{2-}$ formation during heavy haze episodes in northern China. The reaction conditions were a low T, high RH, and weak light (Elser et al., 2016), and it was speculated that $\mathrm{SO}_{4}{ }^{2-}$ formation is the gas-phase reaction of $\mathrm{OH}$ oxidation $\mathrm{NO}_{2}$ and $\mathrm{SO}_{2}$. The reaction conditions were warm winter $\mathrm{Ts}$ and high $\mathrm{O}_{3}$, $\mathrm{HONO}$, and $\mathrm{NH}_{3}$ concentrations.

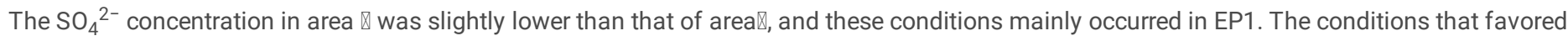
$\mathrm{SO}_{4}{ }^{2-}$ formation were the highest $\mathrm{SO}_{2}$ and $\mathrm{NO}_{2}$ concentrations, and the highest $\mathrm{RH}(63.8 \%)$. The disadvantages for $\mathrm{SO}_{4}{ }^{2-}$ formation were the very low $\mathrm{T}\left(-16^{\circ} \mathrm{C}\right)$, weak light levels, low $\mathrm{O}_{3}$ concentration, and slightly lower SOR (Figure 11). When using the anion/cation equivalent ratio (AE/CE) to evaluate the aerosol acidity (Wang et al., 2016), it was found that the average $\mathrm{AE} / \mathrm{CE}$ of total cations $\left(\mathrm{NH}_{4}{ }^{+}, \mathrm{Na}^{+}, \mathrm{K}^{+}, \mathrm{Ca}^{2+}, \mathrm{Mg}^{2+}\right)$ and anions $\left(\mathrm{SO}_{4}{ }^{2-}, \mathrm{NO}_{3}{ }^{-}, \mathrm{Cl}^{-}\right)$ was $1.07 \pm 0.21$. After the cations had completely neutralized the anions, there were still small amounts of cations remaining. This indicated that $P M_{2.5}$ was approximately neutral or weakly alkaline. Cheng et al. (2016) also studied the causes of $\mathrm{SO}_{4}{ }^{2-}$ formation under the same conditions (high $\mathrm{NO}_{2}$, low $\mathrm{O}_{3}$, and high $\mathrm{RH}$ ) during Beijing haze, and speculated that $\mathrm{NO}_{2}$ may be an important oxidant for fine aerosols under conditions with high $\mathrm{RH}$ and $\mathrm{NH}_{3}$ neutralization. A high $\mathrm{pH}$ value will draw more $\mathrm{SO}_{2}$ into the aerosol droplets, thereby increasing the rate of $\mathrm{SO}_{4}{ }^{2-}$ formation in the $\mathrm{NO}_{2}$ reaction pathway. It is more likely that $\mathrm{NO}_{2}$ will oxidize $\mathrm{SO}_{2}$ in the aqueous phase on fine aerosols with a high $\mathrm{RH}(>60-70 \%)$ and sufficient neutralization ( $\mathrm{pH} 7$ ) (Wang et al., 2016a). Therefore, it was speculated that the increase in $\mathrm{SO}_{4}{ }^{2-}$ production under high $\mathrm{NO}_{2}$ and $\mathrm{SO}_{2} \mathrm{Concentrations}$, high $\mathrm{RH}$, and low $\mathrm{O}_{3}$ levels in northeast China haze events may have a specific mechanism. Under neutral or weakly alkaline conditions, the high pH will pull more $\mathrm{SO}_{2}$ into the aerosol water, and the high $\mathrm{RH}$ will also make it easier for $\mathrm{NO}_{2}$ to react with $\mathrm{SO}_{2}$ droplets in an aqueous oxidation to increase the $\mathrm{SO}_{4}{ }^{2-}$ production rate. This is another important reaction pathway for the production of high $\mathrm{SO}_{4}{ }^{2-}$ concentrations in northeast China in addition to the gasphase transformation under the influence of the photochemical activity in area $\searrow$. However, due to the unique low- $\mathrm{T}$ environment and low $\mathrm{SO}_{2}$ emissions in northeast China in winter, the aqueous phase reaction of $\mathrm{SO}_{4}{ }^{2-}$ in area $\nabla$ was actually substantially weakened, and the gas-phase $\mathrm{SO}_{4}{ }^{2-}$ formation in

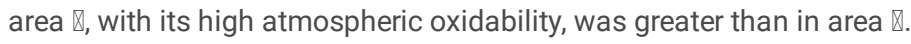

Hong et al. (2019) described seven pollution episodes that occurred in Shenyang from January to April, 2014.The EP1-EP3 reported by Hong et al.

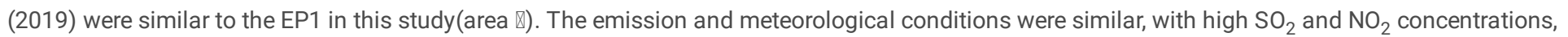
high $\mathrm{RH}$, low $\mathrm{O}_{3}$ concentrations, and weak light conditions.EP5 in Hong et al. (2019) was similar to EP4 in this study(area邓), both of which had low $\mathrm{SO}_{2}$ and $\mathrm{NO}_{2}$ concentrations, low $\mathrm{RH}$, high $\mathrm{O}_{3}, \mathrm{HONO}$, and $\mathrm{NH}_{3}$ concentrations, and a high atmospheric oxidability. The $\mathrm{SO}_{4}{ }^{2-}$ formation was also very similar. The pollutant formation pathway in area $\otimes$ might be high-photochemical oxidation or gas-phase oxidation, while area $\nabla$ was an aqueous phase reaction process. Moreover, the $\mathrm{SO}_{4}{ }^{2-}$ concentration produced by gas-phase oxidation was higher than that produced by aqueous phase oxidation. However, gas-phase oxidation often occurred after March in late winter and early spring. Most of the time $\mathrm{SO}_{4}{ }^{2-}$ was produced by an aqueous phase reaction, but the highest concentration and the fastest formation occurred through the gas-phase reaction. Studies in Beijing-Tianjin-Hebei and other regions have shown that the aqueous reaction is the most important reaction pathway for the rapid growth of $\mathrm{SO}_{4}{ }^{2-}(\mathrm{Sun}$ et al., 2013$)$. Huang et al. (2015) also reported that the conversion of $\mathrm{SO}_{2}$ to $\mathrm{SO}_{4}{ }^{2-}$ during winter haze occurred mainly on the surface of aerosol droplets through catalytic oxidation in the presence of transition metals, rather than by gas-phase oxidation. Wang et al. (2016a) studied the heavy pollution formation process 
in Beijing-Tianjin-Hebei and the entire North China region in autumn and winter. They also found and confirmed that the aqueous oxidation of $\mathrm{NO}_{2}$ on atmospheric fine particles is an important $\mathrm{SO}_{4}{ }^{2-}$ formation mechanism during haze episodes in China. The gas-phase oxidation process was not important. However, in northeast China, due to the inhibitory effect of the low $\mathrm{T}$ in winter on the $\mathrm{SO}_{4}{ }^{2-}$ aqueous reaction, there is rapid $\mathrm{SO}_{4}{ }^{2-}$ and $\mathrm{NO}_{3}{ }^{-}$ production, and the rapid gas-phase oxidation process plays an important role. This is the main difference between northeast China and other regions. However, the aqueous reaction is still the most common way of producing $\mathrm{SO}_{4}{ }^{2-}$ in northeast China.

The $\mathrm{SO}_{4}{ }^{2-}$ concentrations in areas $₫$ and $\llbracket$ were similar. The largest advantage of area $\nabla$ in terms of $\mathrm{SO}_{4}{ }^{2-}$ formation was the high $\mathrm{RH}$, but there were low $\mathrm{SO}_{2}$ and $\mathrm{NO}_{2}$ concentrations and a low $\mathrm{T}$, which inhibited the heterogeneous oxidation of $\mathrm{NO}_{2}$ and $\mathrm{SO}_{2}$ to a certain extent, resulting in a low $\mathrm{SO}_{4}{ }^{2-}$ concentration. The biggest advantage of area $\nabla$ in terms of $\mathrm{SO}_{4}{ }^{2-}$ formation was the high $\mathrm{T}$ in winter, but the low $\mathrm{SO}_{2}$ and $\mathrm{NO}_{2} \mathrm{Concentrations}$ and

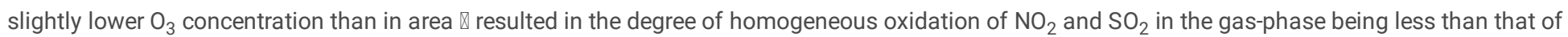

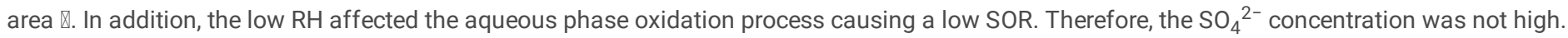

Table 3

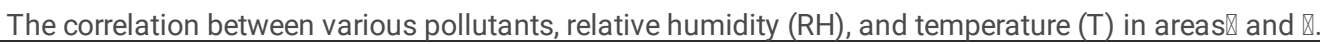

\begin{tabular}{|c|c|c|c|c|c|c|c|c|c|c|}
\hline & $\mathrm{NO}_{3}^{-}$ & $\mathrm{SO}_{4}^{2-}$ & $\mathbf{T}$ & RH & $\mathrm{e}^{\star}$ & $\mathrm{SO}_{2}$ & $\mathrm{NO}_{2}$ & SOR & NOR & $\mathrm{O}_{3}$ \\
\hline $\mathrm{NO}_{3}{ }^{-}$ & 1 & $.663^{\star \star}$ & -.056 & .212 & .071 & .009 & .144 & .217 & $.533^{\star \star}$ & .115 \\
\hline $\mathrm{SO}_{4}{ }^{2-}$ & $.822^{\star \star}$ & 1 & $-.336^{*}$ & $.434^{\star \star}$ & -.130 & $.305^{\star}$ & .290 & .063 & .202 & -.054 \\
\hline $\mathrm{T}$ & $.348^{\star \star}$ & $.110^{*}$ & 1 & $-.681^{\star \star}$ & $.820^{\star *}$ & -.020 & -.010 & -.248 & -.044 & -.081 \\
\hline $\mathrm{RH}$ & .029 & $.135^{\star \star}$ & $-.524^{\star \star}$ & 1 & -.153 & .261 & .249 & -.056 & -.038 & .011 \\
\hline$e^{*}$ & $.463^{\star \star}$ & $.231^{\star \star}$ & $.828^{\star \star}$ & -.009 & 1 & .163 & .169 & $-.354^{*}$ & -.088 & -.116 \\
\hline $\mathrm{SO}_{2}$ & $.123^{\star \star}$ & $.338^{\star \star}$ & $-.207^{\star \star}$ & $.184^{\star \star}$ & $-.115^{\star *}$ & 1 & $.817^{\star \star}$ & $-.793^{\star \star}$ & $-.585^{\star *}$ & $-.657^{\star \star}$ \\
\hline $\mathrm{NO}_{2}$ & $.344^{\star *}$ & $.426^{\star *}$ & .050 & $.089^{*}$ & $.122^{\star \star}$ & $.687^{\star *}$ & 1 & $-.780^{\star \star}$ & $-.696^{* *}$ & $-.657^{\star *}$ \\
\hline SOR & $.490^{\star \star}$ & $.428^{\star \star}$ & $.275^{\star \star}$ & $-.110^{*}$ & $.268^{\star \star}$ & $-.519^{\star \star}$ & $-.316^{* *}$ & 1 & $.820^{\star *}$ & $.642^{\star *}$ \\
\hline NOR & $.752^{\star *}$ & $.566^{\star *}$ & $.354^{\star \star}$ & -.064 & $.400^{\star *}$ & $-.198^{\star \star}$ & $-.169^{\star *}$ & $.773^{\star *}$ & 1 & $.576^{\star \star}$ \\
\hline $\mathrm{O}_{3}$ & $.216^{\star *}$ & .044 & $.628^{\star \star}$ & $-.412^{\star \star}$ & $.505^{\star \star}$ & $-.459^{\star \star}$ & $-.288^{\star \star}$ & $.473^{\star \star}$ & $.390^{\star \star}$ & 1 \\
\hline
\end{tabular}

Note: **. The correlation was significant at the 0.01 level. *. The correlation was significant at the 0.05 level. The lower left side of the table represents

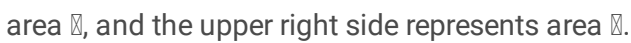

\subsubsection{The influence of $\mathrm{T}$ and $\mathrm{RH}$ on the concentration of important chemical components}

(1) Changes with T:

The $\mathrm{NO}_{3}{ }^{-}$concentration increased with increasing $\mathrm{T}$ (Figure 12). Higher Ts are conducive to $\mathrm{NO}_{3}{ }^{-}$formation in the gas-phase, but Ts below $4{ }^{\circ} \mathrm{C}$ will not support volatilization and therefore will affect the gas particle distribution in the $\mathrm{NH}_{3}+\mathrm{HNO}_{3} \leftrightarrow \mathrm{NH}_{4} \mathrm{NO}_{3}$ reaction. The formation of $\mathrm{SO}_{4}{ }^{2-}$ was similar to that $\mathrm{OC}$ and followed a V-shaped pattern. Higher Ts in winter were beneficial to $\mathrm{SO}_{4}{ }^{2-}$ formation because with high Ts the solar radiation is strong, the rate of photochemical oxidation is rapid, and the $\mathrm{OH}$. concentration increases, which in turn strengthens the oxidation of $\mathrm{SO}_{2}$. Under a high $\mathrm{RH}$, the water content of aerosols is relatively high, and $\mathrm{O}_{3}$ is dissolved in aerosol water where it reacts with dissolved $\mathrm{SO}_{2}$ to promote the liquid-phase oxidation process (Cheng et al., 2016). Heating emissions increase as the $\mathrm{T}$ falls, and therefore large amount of $\mathrm{SO}_{2}$ are generated. The $\mathrm{OC}$ increases with an increase in T, with a higher T meaning that the photochemical reaction was strong, which was conducive to OC formation(Li et al.,2016,2019).

(2) Changes with $\mathrm{RH}$ :

The highest $\mathrm{OC}, \mathrm{NO}_{3}{ }^{-}$, and $\mathrm{SO}_{4}{ }^{2-}$ concentrations were observed when $\mathrm{RH}$ was in the range of $80-90 \%$ (Figure 12). Under a high $\mathrm{RH}$, many atmospheric heterogeneous reactions are accelerated, and the reaction products are conducive to water absorption and the deliquescence of particulate matter. They will therefore have a significant role in promoting haze formation. The coexistence of pollutant particles and fog forms a positive feedback mechanism, which will continuously promote the conversion of the gaseous pollutants discharged from the primary to secondary aerosol. This will result in their concentration continuing to increase. The $\mathrm{SO}_{4}{ }^{2-}$ concentration in this study increased with an increase in $\mathrm{RH}$. This shows the importance of the heterogeneous reactions (liquid phase reactions) under a high $\mathrm{RH}$ in $\mathrm{SO}_{4}{ }^{2-}$ formation. 
Unlike $\mathrm{OC}$ and $\mathrm{SO}_{4}{ }^{2-}$, more than $70-60 \%$ of the $\mathrm{NO}_{3}{ }^{-}$was produced when the $\mathrm{RH}$ was $50-30 \%$. The phenomenon in which the $\mathrm{NO}_{3}{ }^{-}$concentration produced by the EP4 process (low RH) was higher than that of produced during the EP1 process (high $\mathrm{RH}$ ) was explained in section 3.3.1. Wang et al. (2014) also reported a high $\mathrm{NO}_{3}{ }^{-}$production under a low $\mathrm{RH}$. This shows that the dependence of $\mathrm{NO}_{3}{ }^{-}$on $\mathrm{RH}$ was not as obvious as that of $\mathrm{SO}_{4}{ }^{2-}$. Many studies have reported the phenomenon in which the change of the $\mathrm{NO}_{3}{ }^{-}$concentration at different $\mathrm{RH}$ levels in winter is much smaller than that of $\mathrm{SO}_{4}{ }^{2-}$ (Sun et al., 2013). The $\mathrm{NO}_{3}{ }^{-}$formation was more complicated than that of $\mathrm{SO}_{4}{ }^{2-}$. Section 3.3.1 of this article shows that a high atmospheric oxidability, high $\mathrm{NH}_{3}$, high $\mathrm{NO}_{2}$, and high $\left[\mathrm{NH}_{4}^{+}\right]_{\text {excess }}$ were all important in $\mathrm{NO}_{3}$ formation.

Compared with $\mathrm{NO}_{3}{ }^{-}$and $\mathrm{SO}_{4}{ }^{2-}, \mathrm{RH}$ had little effect on the changes in the OC concentration. In this study, the $\mathrm{RH}$ during EP4 was not high, but the OC and SOC concentrations were the highest during the whole three years (2017-2019), which was related to the high $\mathrm{O}_{3}$ concentration, high atmospheric oxidability, and high T during this episode (see section 2.1 for details). Sun et al. (2013) reported that among the organic components, those emitted from coal combustion increased most obviously with an increase in $\mathrm{RH}$. The influence of fog on $\mathrm{SO}_{4}{ }^{2-}$ formationin winter in Beijing can be high, accounting for $70 \%$ of the overall formation, while its influence on $\mathrm{NO}_{3}{ }^{-}$was less than $30 \%$. Our results showed that $\mathrm{RH}$ had the largest impact on $\mathrm{SO}_{4}{ }^{2-}$, followed by $\mathrm{NO}_{3}{ }^{-}$, and had the least impact on OC.

\section{Conclusion}

Based on the simultaneous observations of $\mathrm{PM}_{2.5}$ and its chemical components at 14 sampling sites in northeast China in four severe haze pollution processes during 2017-2019, pollution formation under low T and low-sulfur coal emission conditions were analyzed. Changes in the formation and presence of the secondary pollutants $\mathrm{SO}_{4}{ }^{2-}$ and $\mathrm{NO}_{3}{ }^{-}$under different meteorological and emission scenarios were assessed. The following conclusions were reached.

(1). The most polluted areas in northeast China were in Harbin and its surrounding suburbs and rural areas, followed by Shenyang. The most important component of $\mathrm{PM}_{2.5}$ was $\mathrm{OC}$, followed by SNA. Nitrate has surpassed $\mathrm{SO}_{4}{ }^{2-}$ as the most important secondary inorganic component in northeast China. The main chemical components affecting haze pollution in northeast China were organic matter and inorganic water-soluble ions. The $\mathrm{OC}$ and EC concentrations in urban sites were high, reflecting the contribution of motor vehicles, residential heating, and combustion. The higher $\mathrm{OC}$ and $\mathrm{EC}$ concentrations in the rural sites reflect that the combustion of civilian biomass and the combustion of loose coal has become the largest source of pollutants in the suburbs and rural sites. The ratio of the two was $50.5 \%$.

(2) The significant increase in $\mathrm{OC}, \mathrm{SO}_{4}{ }^{2-}$, and $\mathrm{NO}_{3}{ }^{-}$concentrations was an important reason for haze formation. Meteorological factors such as wind direction, wind speed, $\mathrm{T}, \mathrm{RH}$, and atmospheric oxidability played an important role in secondary pollutant formation. High atmospheric oxidability was very important for $\mathrm{NO}_{3}{ }^{-}$and $\mathrm{SO}_{4}{ }^{2-}$ formation in northeast China.

$\llbracket$ Nitrate formation was mainly due to the homogeneous gas-phase reactions of $\mathrm{OH} \cdot$ with $\mathrm{NO}_{2}, \mathrm{SO}_{2}$, and $\mathrm{NH}_{3}$. The highest concentration occurred under mild winter Ts, high $\mathrm{RH}$, high atmospheric oxidability $\left(\mathrm{O}_{3}\right.$ and $\left.\mathrm{HONO}\right)$, high $\mathrm{NH}_{3}$ concentrations, and suitable light conditions.

$\nabla \mathrm{The} \mathrm{SO}_{4}{ }^{2-}$ concentration tended to increase with an increase in vapor pressure $\left(\mathrm{e}^{\star}\right)$. There were two main $\mathrm{SO}_{4}{ }^{2-}$ formation pathways. One was the gas-phase reaction of the $\mathrm{OH}$ oxidation of $\mathrm{NO}_{2}$ and $\mathrm{SO}_{2}$. High $\mathrm{O}_{3}$ concentrations, higher winter Ts, and high atmospheric oxidability and photochemical activity were very important for $\mathrm{SO}_{4}{ }^{2-}$ formationduring haze events. The second pathway operated under neutral or weakly alkaline conditions, during which $\mathrm{SO}_{2}$ enters aerosol droplets, and $\mathrm{NO}_{2}$ is more likely to react in the aqueous phase with $\mathrm{SO}_{2}$ to increase the output of $\mathrm{SO}_{4}{ }^{2-}$. The difference between the $\mathrm{SO}_{4}{ }^{2-}$ formationin northeast China and other regions was reflected by the suppression of the aqueous reaction of $\mathrm{SO}_{4}{ }^{2-}$ due to low Ts in winter and low-sulfur coal emissions in northeast China. This resulted in the rapid generation of gas-phase oxidation processes being important for high levels of $\mathrm{SO}_{4}{ }^{2-}$ production in the region. However, the aqueous oxidation reaction was still the most common $\mathrm{SO}_{4}{ }^{2-}$ formation pathway in northeast China.

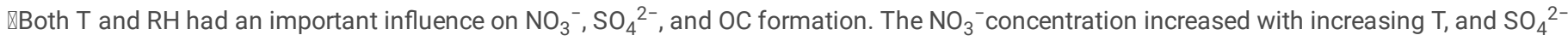
concentration, with the $\mathrm{SO}_{4}{ }^{2-}$ following a similar V-shaped pattern to that of $\mathrm{OC}$. The highest $\mathrm{NO}_{3}{ }^{-}$and $\mathrm{SO}_{4}{ }^{2-}$ concentrations occurred when the $\mathrm{RH}$ was $80-90 \%$. The effect of $\mathrm{RH}$ on $\mathrm{NO}_{3}{ }^{-}$was not as significant as that of $\mathrm{SO}_{4}{ }^{2-}$, but $\mathrm{NO}_{3}{ }^{-}$formationwas more complicated, being affected by multiple factors, such as RH and photochemical activity. The OC concentration increased with $\mathrm{T}$, and RH had little effect on the changes in the OC concentration.

\section{Declarations}

Funding information This research was funded by the Institute of the Atmospheric Environment, China Meteorological Administration, Shenyang (2021SYIAEZD2,2017SYIAEMS6); Scientific and Technological Research Project of Liaoning Meteorological Bureau (202012,201502); the Institute of Atmospheric Physics, Chinese Academy of Sciences (LAPC-KF-2017-02); the Laboratory of Atmospheric Boundary Layer Physics and Atmospheric Chemistry, Special Forecast Core Business Development Projects (CMAHX20160307); the National Key R\&D Program of China (2017YFC021230101); 
the Natural Science Foundation of Liaoning Province (2020-MS-350), Liaoning Key Guidance Project of Research and Invention

Plan(2019JH8/10300094), and the National Natural Science Foundation of China(41730647)

\section{Compliance with ethical standards}

\section{Ethics approval and consent to participate Not applicable}

Consent to Publish Not applicable

Conflict of interest The authors declare that they have no competing interests

The authors have no relevant financial or non-financial interests to disclose.

The authors have no competing interests to declare that are relevant to the content of this article.

All authors certify that they have no affiliations with or involvement in any organization or entity with any financial interest or non-financial interest in the subject matter or materials discussed in this manuscript.

The authors have no financial or proprietary interests in any material discussed in this article.

Authors are responsible for correctness of the statements provided in the manuscript.

Authors' contributions All authors contributed to the study conception and design. Material preparation, data collection and analysis were performed by Junying Sun, Yanjun Ma『Yangfeng Wang,Xiaolan Li,Yunhai Zhang, Ningwei Liu囚Hujia Zhao and Deping Zhou. The first draft of the manuscript was written by Ye hong and all authors commented on previous versions of the manuscript. All authors read and approved the final manuscript.

Availability of data and materials Not applicable

Publisher's Note Springer Nature remains neutral with regard to jurisdictional claims in published maps and institutional affiliations.

\section{References}

1. An JL, Li Y, Tang YJ, Chen Y, Qu Y (2014) Advances in HONO sources, HONO simulations, and the impacts of the HONO sources on regional or global air quality. China Environmental Science 34(2):273-281

2. Cao GL, An XQ, Zhou CH,Ren YQ,Tu J (2010) Emission inventory of air pollutants in China. China Environmental Science 30, $900-906$.

3. Cao JJ, Wu F, Chow JC, et al.(2005) Characterization and source apportionment of atmospheric organic and elemental carbon during fall and winter of 2003 in Xi'an, China. Atmospheric Chemistry and Physics,5( 11): 3127-3137.

4. Chameides WL, Yu H, Liu S C, Liu M, Bergin X, Zhou L, Mearns G, Wang C S, Kiang R D, Saylor C, Luo Y, Huang A (1999) Case study of the effects of atmospheric aerosols and regional haze on agriculture, An opportunity to enhance crop yields in China through emission controls. Proceedings of the National Academy of Sciences of the United States of America 96(24) : 13626-13633.

5. Cheng YF, Zheng GJ, Wei C, Mu Q, Zheng B, Wang ZB, Gao M, Zhang Q, He KB, Carmichael, GR, Pöschl, U, \& Su, H (2016) Reactive nitrogen chemistry in aerosol water as a source of sulfate during haze events in China. Science Advances 2:2375-2548.

6. Elser M, Huang RJ, Wolf R, Slowik JG, Wang Q, Canonaco F, Li G, Bozzetti C, Daellenbach KR, Huang Y, Zhang R, Li Z, Cao J, Baltensperger U, ElHaddad I, \& Prévôt AS (2015) New insights into PM 2.5 chemical composition and sources in two major cities in China during extreme haze events using aerosol mass spectrometry. Atmospheric Chemistry and Physics 15: 3207-3225.

7. Finlayson-Pitts BJ, Wingen LM, Sumner AL, Syomin D, \& Ramazan KA (2003) The heterogeneous hydrolysis of $\mathrm{NO}_{2}$ in laboratory systems and in outdoor and indoor atmospheres: An integrated mechanism. Physical Chemistry Chemical Physics 5: $223-242$.

8. Ge X, Zhang Q, Sun Y, Ruehl CR, \& Setyan A (2012) Effect of aqueous-phase processing on aerosol chemistry and size distributions in Fresno, California, during wintertime. Environmental Chemistry 9: 221-235.

9. Tang G , Bo H , Wang L , Ji D, Wang Y , \& Liu Z , et al. (2014). Researching significance, status and expectation of haze in beijing-tianjin-hebei region. Advances in Earth Science, 29(3). , 388-396.

10. Guo H, Weber RJ, \& Nenes A (2017) High levels of ammonia do not raise fine particle pH sufficiently to yield nitrogen oxide-dominated sulfate production. Scientific Reports 7.

11. Harris E, Sinha B, van Pinxteren D, Tilgner A, Fomba KW, Schneider J, Roth A, Gnauk T, Fahlbusch B, Mertes SC, Lee T, Collett JL, Foley SP, Borrmann S, Hoppe P, \& Herrmann H, (2013) Enhanced Role of Transition Metal lon Catalysis During In-Cloud Oxidation of $\mathrm{SO}_{2}$. Science 340 : 727 730.

12. Han LH, Chen YY, Jia L, et al. (2014). Heterogeneous reactions of NO2 on MgO particle surfaces. Science China Chemistry,44(12):2004-2012.

13. He L, Hu M, Huang X, Yu B, Zhang Y, \& Liu D (2004) Measurement of emissions of fine particulate organic matter from Chinese cooking. Atmospheric Environment 38, 6557-6564. 
14. Hong Y, Ma Y, Sun J, Li C, Zhang Y, Li X, Zhou D, Wang Y, \& Liu N (2019) Water-soluble ion components of $\mathrm{PM}_{10}$ during the winter-spring season in a typical polluted city in northeast China. Environmental Science and Pollution Research 26: 7055-7070.

15. Hu WW, Hu M, Deng ZQ, Xiao R, Kondo Y, Takegawa N, Zhao YJ, Guo S, Zhang YH (2012) The characteristics and origins of carbonaceous aerosol at a rural site of PRD in summer of 2006. Atmospheric Chemistry and Physics 12: 1811-1822.

16. Hu YQ, Ma ZH, Feng YJ, Wang C, Chen YY, He M (2015) Emission characteristics of water-soluble ions in fumes of coal fired boilers in Beijing. Environmental Sciences 36(6):1966-1974.

17. Huang X, Liu Z, Zhang J, Wen T, Ji D, \& Wang Y (2016) Seasonal variation and secondary formation of size-segregated aerosol water-soluble inorganic ions during pollution episodes in Beijing. Atmospheric Research 168: 70-79.

18. Ji D, Gao W, Zhang J, Morino Y, Zhou L, Yu P, Li Y, Sun J, Ge B, Tang G, Sun Y, \& Wang Y, (2016) Investigating the evolution of summertime secondary atmospheric pollutants in urban Beijing. The Science of the total environment 572: 289-300 .

19. Li C, Bosch Carme, Kang SC, et al., 2016. Sources of black carbon to the Himalayan-Tibetan Plateau glaciers. Nature Communications, 7: 12574.

20. Li C, Han XW, Kang SC, et al.(2019) Heavy near-surface $\mathrm{PM}_{2.5}$ pollution in Lhasa, China during a relatively static winter period. Chemosphere, 214: 314-318.

21. Li H, Duan F, Ma Y, He K, Zhu L, Ma T, Ye S, Yang S, Huang T, \& Kimoto T (2018a) Haze pollution in winter and summer in Zibo, a heavily industrialized cityneighboring the Jing-Jin-Ji area of China: source, formation, and implications. Atmospheric Chemistry and Physics:1-40.

22. Li J, Du H, Wang Z, Sun Y, Yang W, Li J, Tang X, \& Fu P (2017) Rapid formation of a severe regional winter haze episode over a mega-city cluster on the north China Plain. Environmental pollution 223: 605-615.

23. Li L, Hoffmann MR, \& Colussi AJ (2018b) Role of nitrogen dioxide in the production of sulfate during Chinese haze-aerosol episodes. Environmental science \& technology 52(5): 2686-2693 .

24. Li YH, Duan JC, Zheng NJ, Zheng NJ, Tan JH, Rao ZG, Ma YL, He KB (2015) Characteristics of organic and element carbon in fine particles in Lanzhou囚Journal of University of Chinese Academy of Sciences 32( 4) : 490-497囚

25. Liu X, Sun K, Qu Y, Hu M, Sun Y, Zhang F, \& Zhang Y (2015) Secondary formation of sulfate and Nitrate during a haze episode in megacity Beijing, China. Aerosol and Air Quality Research 15: 2246-2257.

26. Luo L, Zhu R, Song C, Peng J, Guo W, Liu Y, Zheng N, Xiao H, \& Xiao H (2021) Changes in nitrate accumulation mechanisms as PM 2.5 levels increase on the north China Plain: A perspective from the dual isotopic compositions of nitrate. Chemosphere $263: 127915$.

27. Pathak RK, \& Chan CK (2005) Inter-particle and gas-particle interactions in sampling artifacts of $\mathrm{PM}_{2.5}$ in filter-based samplers. Atmospheric Environment 39: 1597-1607.

28. Pathak RK, Wu W, \& Wang T (2008) Summertime $\mathrm{PM}_{2.5}$ ionic species in four major cities of China: nitrate formation in an ammonia-deficient atmosphere. Atmospheric Chemistry and Physics 9: 1711-1722.

29. Schauer JJ, Kleeman MJ, Cass GR, \& Simoneit BR (2002) Measurement of emissions from air pollution sources. 5. C1-C32 organic compounds from gasoline-powered motor vehicles. Environmental science \& technology 36(6): 1169-80 .

30. Seinfeld JH, Pandis SN (2006) Atmospheric chemistry and physics: from air pollution to climate change, seconded. John Wiley \& Sons, New York.

31. Shi Y, Chen JM, Hu DW, Wang L, Yang X, Wang XM (2014) Airborne submicron particulate ( $\left.\mathrm{PM}_{1}\right)$ pollution in Shanghai, China: Chemical variability, formation/dissociation of associated semi-volatile734 components and the impacts on visibility. Science of the Total Environment 473 : $199-206$.

32. Shi XR (2019) Study on the relationship between atmospheric aerosol pH and secondary nitrate based on online observed data. Nankai University.

33. Sobhani N, Kulkarni S, and Carmichael G R (2018) Source sector and region contributions to black carbon and PM 2.5 in the Arctic, Atmospheric Chemistry and Physics 18: 18123-18148.

34. Sun Y, Chen C, Zhang Y, Xu W, Zhou L, Cheng X, Zheng H, Ji D, Li J, Tang X, Fu P, \& Wang Z (2016) Rapid formation and evolution of an extreme haze episode in northern China during winter 2015. Scientific Reports, 6.

35. Sun YL (2018) Vertical structures of physical and chemical properties of urban boundary layer and formation mechanisms of atmospheric pollution. Chinese Science Bulletin 63: 1374-1389.

36. Sun YL, Wang Z, Dong H, Yang T, Li J, Pan X, Chen P, \& Jayne JT (2012) Characterization of summer organic and inorganic aerosols in Beijing, China with an aerosol chemical speciation monitor. Atmospheric Environment 51: 250-259.

37. Sun YL, Wang Z, Fu P, Jiang Q, Yang T, Li J, \& Ge X (2013) The impact of relative humidity on aerosol composition and evolution processes during wintertime in Beijing, China. Atmospheric Environment 77: 927-934.

38. Tan JH, Duan JC, Chen DH et al (2009) Chemical characteristics of haze during summer and winter in Guangzhou. Atmospheric research, 94(2):238-245.

39. Tang XY, Zhang YH, Shao M (2006) Atmospheric environmental chemistry second edition. Higher Education Press.

40. van Donkelaar A, Martin RV, Brauer M, Hsu NC, Kahn RA, Levy RC, Lyapustin Al, Sayer AM, \& Winker DM (2016) Global estimates of fne particulate matter using a combined geophysical-statistical method with Information from satellites, models, and monitors. Environmental science \& technology 50 7: 3762-3772. 
41. Wang C, Cao JY, Duan XL, Chen H, Yan YL, Peng L (2021a) Characteristecs and sources analyais of carbonaceous components in PM ${ }_{2.5}$ in winter in four cities of Shanxi province. Environmental Engineering 39(06):114-121.

42. Wang G, Zhang R, Gómez ME, Yang L, Levy Zamora M, Hu M, Lin Y, Peng J, Guo S, Meng J, Li J, Cheng C, Hu T, Ren Y, Wang Y, Gao J, Cao J, An Z, Zhou W, Li G, Wang J, Tian P, Marrero-Ortiz W, Secrest J, Du Z, Zheng J, Shang DJ, Zeng L, Shao M, Wang W, Huang Y, Wang Y, Zhu Y, Li Y, Hu J, Pan B, Cai L, Cheng Y, Ji Y, Zhang F, Rosenfeld D, Liss PS, Duce RA, Kolb CE, \& Molina MJ (2016a) Persistent sulfate formation from London fog to Chinese haze. Proceedings of the National Academy of Sciences| 113: 13630 - 13635.

43. Wang H, Lu K, Chen X, Zhu Q, Wu Z, Wu Y, \& Sun K (2018) Large particulate nitrate formation from $\mathrm{N}_{2} \mathrm{O}_{5}$ uptake in a chemically reactive layer aloft during winter time in Beijing. Atmospheric Chemistry and Physics 1-27.

44. Wang Y S, Zhang JK, Wang LL, et al.(2014) Researching significance『status and expectation of haze in Beijing-Tianjin-Hebei region. Advances in Earth Science.29(3): 388-396.

45. Wang W, Liu M, Wang T, Song Y, Zhou L, Cao J, Hu J, Tang G, Chen Z, Li Z, Xu Z, Peng C, Lian C, Chen Y, Pan Y, Zhang Y, Sun Y, Li W, Zhu T, Tian H, \& Ge M (2021b) Sulfate formation is dominated by manganese-catalyzed oxidation of $\mathrm{SO}_{2}$ on aerosol surfaces during haze events. Nature Communications 12(1), 1-10.

46. Wang XQ, Zhou Y, Cheng SY, Wang G (2016b) Characterization and regional transmission impact of water-soluble ions in $P M_{2.5}$ during winter in typical cities. China Environmental Science 36(08):2289-2296.

47. Xu H, Chen JQ, He DT, Cheng P, Wang W, Zhu L, Yang, H, Gu ZQ (2017a) Climatic characteristics of haze weather during heating periods from 1980 to 2015 at Shenyang region (in Chinese). Journal of Meteorology and Environment 33(2):87-94.

48. Xu J, Xu, M Snape CE, He J, Behera SN, Xu H, Ji D, Wang C, Yu H, Xiao H, Jiang Y, Qi B, \& Du R (2017b) Temporal and spatial variation in major ion chemistry and source identification of secondary inorganic aerosols in northern Zhejiang Province, China. Chemosphere 179: 316-330 .

49. Yang L, (2018) Analysis of Pollution Characteristics of EC/OC in $\mathrm{PM}_{2.5}$ in Changchun City. Jilin University.

50. Zhang J, Liu L, Xu L, Lin Q, Zhao H, Wang Z, Guo S, Hu M, Liu D, Shi Z, Huang D, \& Li W, (2020) Exploring wintertime regional haze in northeast China: role of coal and biomass burning. Atmospheric Chemistry and Physics 20: 5355-5372.

51. Zhang Y, Shao M, Zhang Y, Zeng L, He L, Zhu B, Wei Y, \& Zhu X (2007). Source profiles of particulate organic matters emitted from cereal straw burnings. Journal of environmental sciences 192: 167-75.

\section{Figures}

\section{Figure 1}

Locations of the 14 sampling sites in northeast China

\section{Figure 2}

The average concentrations of PM2.5and its chemical components at each sampling site (Note: There are three columns for each sampling site, representing 2017, 2018, and 2019 respectively).

\section{Figure 3}

The concentrations of PM2.5 and its chemical components (OC, SO42-, and NO3-: $\mu \mathrm{gm}-3$ )

\section{Figure 4}

Temporal changes in the concentrations of PM10, PM2.5, and their chemical components and their ratios in PM2.5, as well as the variations in gaseous emissions, meteorological conditions, and the boundary layer height (BLH) in EP1-EP4 

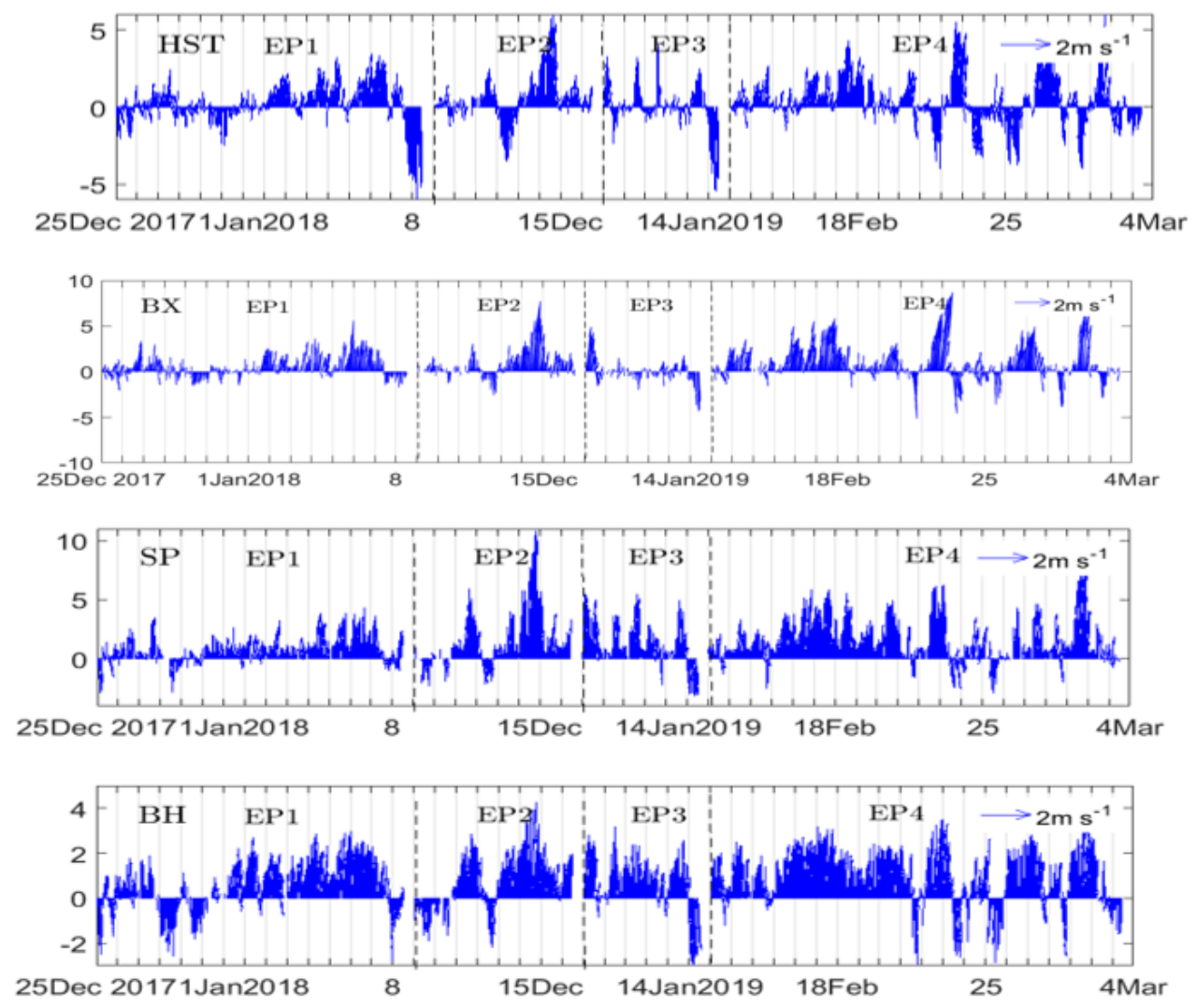

\section{Figure 5}

Time series of the wind direction and wind speed at the main sampling sites

\section{Figure 6}

The PM2.5 concentration and a wind field diagram for EP3, showing the jump point of the PM2.5 concentration

\section{Figure 7}

The PM2.5 concentration and corresponding wind field on February 28, 2019 in EP4

\section{Figure 8}

The relationship between [NH4+] excess and NO3- and NO3-+Cl-. (a) The relationship between [NH4+] excess and NO3-, with the different colors indicating different pollution processes; (b) the relationship between [ $\mathrm{NH} 4+$ ]excess and $\mathrm{NO} 3-+\mathrm{Cl}-$, with the different colors indicating different pollution processes; (c) the colors indicate different levels of relative humidity (RH); and (d) the colors indicate different temperatures (Ts).

\section{Figure 9}

The NO3- and SO42-concentrations and their precursor gases at the SY site

Figure 10

The relationships between SO42- and the sulfur oxidation rate (SOR), ambient water vapor pressure( $\left.\mathrm{e}^{\star}\right)$, relative humidity (RH), and temperature ( $\left.\mathrm{T}\right)$ 

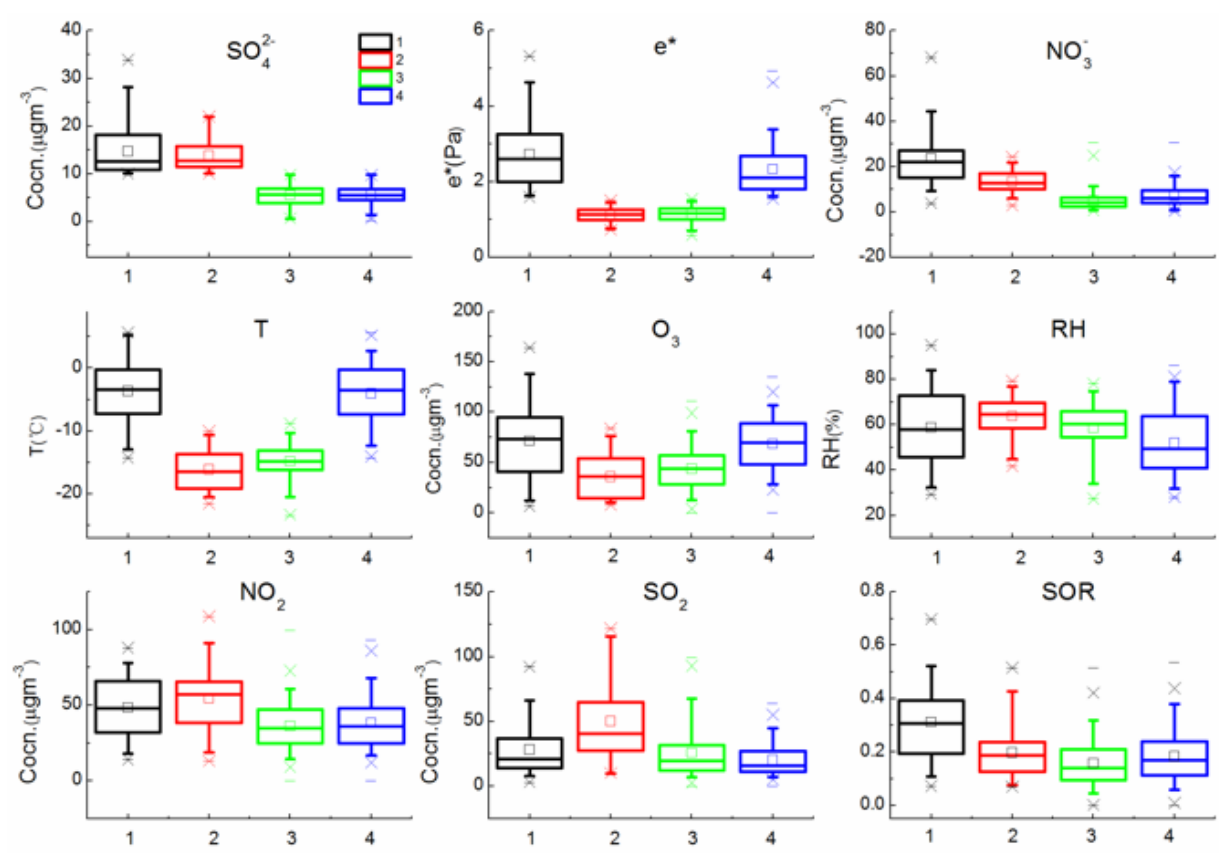

\section{Figure 11}

The statistical values of various pollutants, relative humidity (RH), and temperature $(\mathrm{T})$ in four areas divided by the SO42- concentration and ambient water vapor pressure $\left(\mathrm{e}^{\star}\right)$

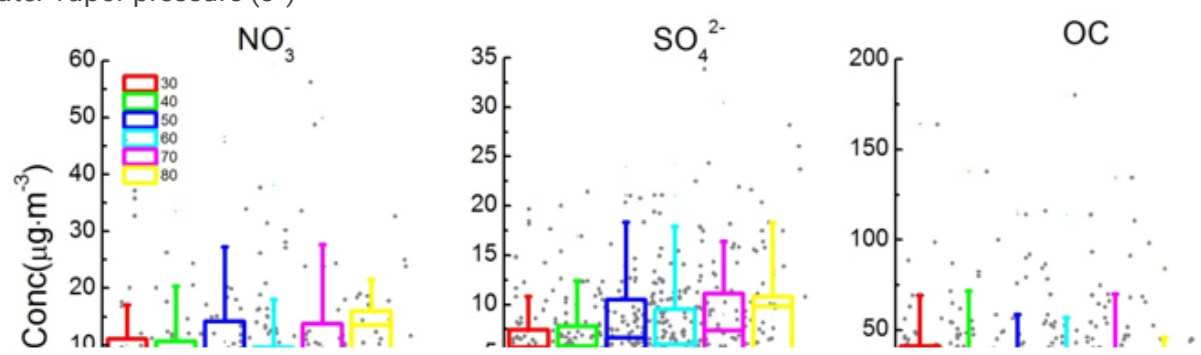

\section{Figure 12}

Diffraction pattern of the diurnal variation of the proportional contents of several important chemical components of PM2.5 